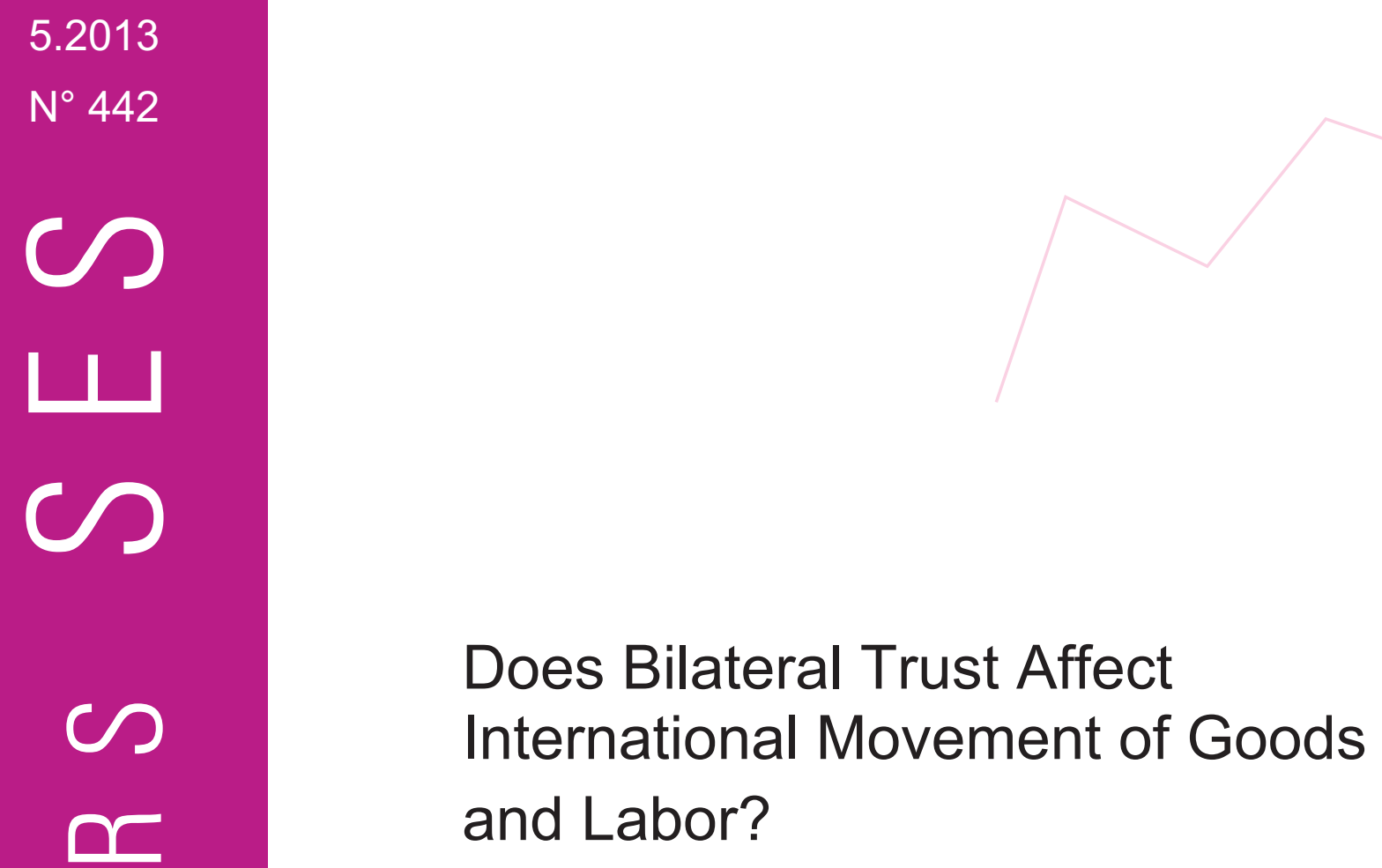

لـ

ص

- Eva Spring and Volker Grossmann

0
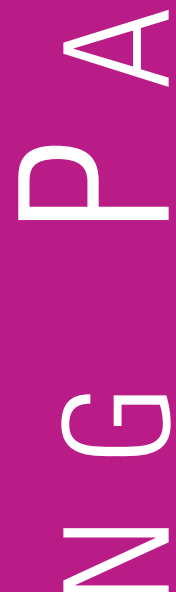
- Eva Spring and Volker Grossmann

Faculté des Sciences Economioues et Sociales Wirtschafts - und Sozialwissenschaftliche Fakultät Université de Fribourg | Universität Freiburg 


\title{
Does Bilateral Trust Affect International Movement of Goods and Labor?*
}

\author{
Eva Spring ${ }^{\dagger}$ and Volker Grossmann ${ }^{\ddagger}$
}

April 30, 2013

\begin{abstract}
Trust in the citizens of a potential partner country may affect the decision to trade with or to migrate to a foreign country. This paper employs panel data to examine the causal impact of such bilateral trust on international trade and migration patterns. We apply instrumental variables (IV) approaches that capture the exogenous variance of bilateral trust separately with eight indicators of genetic ("somatic") distance between country-pairs. These indicators work equally well at the first stage. However, second-stage results very much depend on the exact measure employed as instrument. Overall, we find little evidence that bilateral trust affects international movements of goods and labor. More generally, we highlight the potential fragility of IV estimations even when the instruments seem plausible on theoretical grounds and when standard statistical tests confirm their validity.
\end{abstract}

Key words: Bilateral trust; International migration; International trade; Instrumental variables; Somatic distance.

JEL classification: F10; F22; Z10.

${ }^{*}$ Acknowledgements: We are grateful to Francesc Ortega and Giovanni Peri for providing us with their unique dataset on bilateral gross immigration flows and to Luigi Guiso, Paola Spaienza, and Luigi Zingales for sending us their measure of press coverage. We also thank Joseph Falkinger, Joshua Angrist, Manuel Arellano, Bo Honoré, and Mark Watson as well as seminar participants at the Synergia workshop "Inequality and International Trade" 2012 in Hurden and the Young Swiss Economist Meeting 2013 in Bern for valuable comments and suggestions.

${ }^{\dagger}$ University of Fribourg. Address: University of Fribourg, Departement of Economics, Bd. de Pérolles 90, F410, CH-1700 Fribourg, Switzerland. Phone: +41 (0)26 3009382 . Email: eva.spring@unifr.ch.

$\ddagger$ University of Fribourg; CESifo, Munich; Institute for the Study of Labor (IZA), Bonn. Address: University of Fribourg, Department of Economics, Bd. de Pérolles 90, G424, CH-1700 Fribourg, Switzerland. Phone: +41 (0)26 30093 83. Email: volker.grossmann@unifr.ch 


\section{Introduction}

The study of the effects of trust for international trade is rooted in the general notion that economic exchange is often characterized by asymmetric information which can lead to opportunistic behavior. To prevent this type of behavior, contracts define the obligations of all implied parties. However, contracts are by nature incomplete as it is too costly to take into account or even know all contingencies when establishing them. Furthermore, it can be difficult to monitor and enforce contracts, especially in international trade where the commercial partners are established in different jurisdictions (Rodrik, 2000). As a result, successful trade opportunities might not be realized, unless the parties trust each other (Akerlof, 1970; Arrow, 1972; Putnam, 1993; Grief, 1993, 2000; Coleman, 1994; Kallock, 1994; Fukuyama, 1995; Paldam, 2000). When trade partners are confident that they will not be cheated on, they divert less resources to negotiate, monitor, and enforce contracts (Knack and Keefer, 1997; Dyer and Chu, 2003). By mitigating these transaction costs, the trust citizens of the country importing goods have towards citizens of their partner country, denoted by "Destination-to-Source (DtS) trust", may enhance profitability of trade opportunities and thereby increase the volume of international trade.

In fact, empirical evidence by Guiso, Sapienza, and Zingales (2009, henceforth GSZ) suggests that DtS trust has a significant and economically important causal effect on international trade. To address endogeneity concerns, GSZ isolate the exogenous variation of bilateral trust with two measures of cultural proximity of country-pairs, an indicator of genetic ("somatic") distance and a measure of religious similarity. By doing so, their instrumental variables (IV) estimations overturn the result of estimating a standard gravity-type trade regression with trust as an additional regressor via OLS. The significant point-estimates of the IV coefficients on bilateral trust are more than five times larger than their insignificant OLS counterparts. This increase might simply reflect the reduction of the bias that distorts the OLS coefficient of the potentially endogenous trust variable. Nevertheless, it could equally indicate that there is a problem 
with the instrumentation strategy, statistical tests notwithstanding. ${ }^{1}$

First, this paper reconsiders the relationship between trust and international trade by using seven alternative measures of somatic distance to the one used by GSZ. ${ }^{2}$ In fact, the researcher has a large degree of freedom when constructing an indicator of somatic distance. All of our indicators measure physical dissimilarities between the "average" individual of two countries. They exploit the notion that individuals who look less alike tend to trust each other less. At the same time, physical dissimilarities per se should not have an impact on trade in a way other than through their effect on bilateral trust.

We find that all of our alternative measures of somatic distance are highly correlated with the endogenous trust variable in a similar fashion than the somatic distance variable originally used by GSZ. Moreover, there is no indication of weak identification problems. It should thus not matter for consistent estimates which somatic distance measure we choose to instrument bilateral trust with. Using the indicator of GSZ, we find that an increase of one standard deviation in instrumented DtS trust increases aggregated export flows on average by 24 percent, which basically replicates their original finding. However, the coefficients of bilateral trust become insignificant as soon as we do not use the original indicator by GSZ. With all of our seven alternative indicators, the size of coefficients on instrumented bilateral trust in the trade regressions declines considerably, sometimes even becoming negative. Moreover, the coefficients on the alternative instruments are never significantly different from zero in the reduced form where trade flows are regressed on them. Generally, this suggests that the endogenous variable has no effect on the dependent variable (Angrist and Pischke, 2009).

\footnotetext{
${ }^{1}$ For instance, as discussed by GSZ themselves, religion may shape institutions and thus may affect international trade and other forms of international economic exchange not only through the trust channel. In this case, religious similarity should not be used as an instrument. Therefore, we define an alternative specification including religious similarity as a regressor, focusing on somatic distance measures as instruments.

${ }^{2}$ Three of them are made available in the online-appendix of the paper by GSZ (Guiso et al., 2008a), but are not used in the published version of the paper. Our sensitivity analysis is motivated by the following statement by Murray (2006, p. 119): "If the parameter estimates using different instruments differ appreciably and seemingly significantly from one another, the validity of the instruments becomes suspect."
} 
In sum, contrary to what has been suggested by GSZ, we conclude that a causal effect of bilateral trust on international trade is not supported by the data.

Motivated by this surprising result, second, we re-run our regressions by using international migration rather than trade as dependent variable at the second stage. ${ }^{3}$ Potentially, trust in the citizens of a host country may have an impact on the decision to migrate to a foreign country. Generally, in the absence of important barriers to migration, individuals only migrate to a foreign country if expected migration benefits exceed expected migration costs (Roy, 1951; Sjaastad, 1962; Anderson, 1979; Borjas, 1987, 1989; Grogger and Hanson, 2011). Both benefits and costs may be monetary, such as a higher income in the host country or physical moving costs. They can also be of social or psychological nature. However, forming expectations on such migration costs and benefits is difficult. Migrants are generally not fully aware of the social, political, institutional, and cultural environment of potential host countries. In such a context, their decision to migrate may also rely on the trust they have in citizens of the destination country. This bilateral trust, which we refer to as "Source-to-Destination (StD) trust", might change the way expectations on costs and benefits of moving abroad are formed. Thus, there is reason to believe that StD trust directly affects international migration by changing its expected net return. Likewise, the trust that citizens from the destination country grant citizens from the source country, the DtS trust, may play a role in the migration decision. For instance, it may affect immigration policies towards specific countries or regions.

We measure international migration by the gross immigration flows taken from a unique panel data set established by Ortega and Peri $(2009,2011)$. The pattern which emerges from estimating the relationship between these migration flows and bilateral trust is very similar to our results for trade. When using the original somatic distance indicator by GSZ as instrument, we find that bilateral trust has a significant and positive effect on international migration. More precisely, the results suggest that an increase in StD trust or DtS trust of one standard deviation increases immigration

\footnotetext{
${ }^{3}$ GSZ studied the effect of trust on investment flows, in addition to trade flows, but did not consider migration.
} 
flows on average by 67 percent and 53 percent, respectively. However, when using the seven alternative and equally valid measures of somatic distance as instruments, we are unable to find a significant and quantitatively important effect of trust on migration flows.

This paper is part of a growing literature that analyzes the role of trust for economic outcomes. Prior research suggests various channels through which trust influences economic activity. ${ }^{4}$ Comparing Italian regions, Putnam (1993) finds that trust increases participation in social activities, facilitates cooperation, and improves the effectiveness of institutions. ${ }^{5}$ More recently, empirical studies show that trust fosters economic development and growth also through its positive effect on total factor productivity (Bjornskov, 2010), on financial development (Guiso et al., 2004, 2008b), and on the rate of investment (Knack and Keefer, 1997; Zak and Knack, 2001. Algan and Cahuc (2010) and Tabellini (2010) find a causal effect of inherited and historically determined trust on economic growth. These studies exploit the variation of generalized trust across countries (proposed by the World Values Surveys) to identify its role for differential economic outcomes. By contrast, we are concerned with the effects of bilateral trust on bilateral movement of goods and labor between two countries. To the best of our knowledge, none has yet examined the impact of trust on international migration patterns, a gap that we want to fill in this study.

Our paper hence also contributes to the literature on the determinants of international migration. Since Ravenstein (1885) presented his law of migration, economists devoted considerable energies to study the migration decision. Many empirical papers analyzing migration patterns such as Clark, Hatton and Williamson (2007), Pedersen, Pytlikova and Smith (2008), Mayda (2010), Beine, Docquier and Ozden (2011), Grogger and Hanson (2011), and Beine and Parons (2012) are based on the income

\footnotetext{
${ }^{4}$ As already asserted by Arrow (1972, p. 357): "Virtually every commercial transaction has within itself an element of trust, certainly any transaction conducted over a period of time. It can be plausibly argued that much of the economic backwardness in the world can be explained by the lack of mutual confidence."

${ }^{5}$ On trust and institutions, see also La Porta et al. (1997), Alesina and La Ferrara (2000), Bjornskov (2006), Tabellini (2008, 2010), Bloom, Sadun and Reeen (2009), and Aghion, Algan, Cahuc, and Shleifer (2010).
} 
maximization approach originated by Roy (1951). Our framework is similar to these recent contributions which use gravity-type frameworks to analyze various determinants of international migration but in contrast to this literature focusses on bilateral trust.

Finally, our paper highlights potential fragility of IV estimations. Although the standard statistical tests affirm that the applied IV strategies are equally valid and that the instruments are sufficiently strong, we find that small changes in the construction of an instrument can fundamentally change the results. Our analysis highlights the importance of performing sensitivity analysis with alternative instruments, even when an instrument seems plausible on econometric and theoretical grounds. This is especially true when there is a large degree of freedom in constructing the instruments.

The rest of the paper is organized as follows. The next section analyzes the causal effect of bilateral (DtS) trust on international trade and presents the empirical model, the data, and the results of the sensitivity analysis. Section 3 reports the results of regressing international migration on $\mathrm{StD}$ and $\mathrm{DtS}$ trust, using a similar identification strategy. The last section concludes.

\section{Bilateral Trust and International Trade}

In this section, we examine the effects of Destination-to-Source (DtS) trust on commodity export flows. We first estimate the specification suggested by GSZ with data constructed and collected following their instructions. Moreover, we follow their identification strategy and use their specific measure of somatic distance as an instrument for bilateral trust. In a second step, we investigate the robustness of their results by estimating alternative specifications based on alternative indicators of somatic distance which are equally well correlated with DtS trust. 


\section{$2.1 \quad$ Identification}

To analyze the relationship between DtS trust and international trade, GSZ focus on a specification that takes the following form: ${ }^{6}$

$$
\log \left(\text { export }_{s d, t}\right)=\beta_{0}+\beta_{1} \text { trust }_{d s, t}+\mathbf{X}_{s d}^{\prime} \gamma+\lambda_{s, t}+\lambda_{d, t}+\epsilon_{s d, t},
$$

where the dependent variable, $\log \left(\right.$ export $\left._{s d, t}\right)$, is the natural logarithm of the aggregated commodity export flows from country $s$ to country $d$ in year $t$ and trust $_{d s, t}$ is the DtS trust observed in year $t . \mathbf{X}_{s d}^{\prime}$ is a vector of time-invariant bilateral variables which capture trade costs (Anderson and van Wincoop, 2004). It includes a variable measuring the geographical distance between two countries and dummy variables that take the value 1 when two countries share a border, an official language, or when their legal system has the same origin. Following GSZ, we further include an indicator of press coverage that measures how many times a partner country was mentioned in the national newspapers, a proxy for transportation costs, and a measure of linguistic common roots. The variable can take values between zero and one: it is one when two countries share an official language, zero when the two official languages come from different language families, and it takes values between zero and one when the official languages share some common nods. $\lambda_{s, t}$ and $\lambda_{d, t}$ are time-varying country dummies which account for country- and time-specific determinants of international trade. According to Baldwin and Taglioni (2006), these dummies are supposed to eliminate the bias stemming from the omission of what Anderson and van Wincoop (2003, 2004) call "multilateral resistance" to trade. ${ }^{7}$ The last term in equation (1),

\footnotetext{
${ }^{6}$ This equation is closely related to the standard gravity regression. Since the gravity model was given a theoretical foundation by Anderson (1979), it has been widely used to analyze economic outcomes and it fits the data remarkably well. For a short overview of the origin of the gravity model and the corresponding literature see also Anderson and van Wincoop (2003), Baldwin and Taglioni (2006), Anderson (2011), and Head and Mayer (2013).

${ }^{7}$ As explained by Anderson and van Wincoop (2003, p. 170), " [...] after controlling for size, trade between two regions is decreasing in their bilateral trade barrier relative to the average barrier of the two regions to trade with all their partners. Intuitively, the more resistant to trade with all others a region is, the more it is pushed to trade with a given bilateral partner. We will refer to the theoretically appropriate average trade barrier as 'multilateral resistance'."
} 
$\epsilon_{s d, t}$, is a mean-zero random variable accounting for random shocks.

The inclusion of pair-specific variables and time varying country dummies partially addresses potential mis-specification caused by omitted variables but the OLS estimate of DtS trust $\left(\beta_{1}\right)$ might still be inconsistent because of measurement error or simultaneous causality. In order to identify the causal relationship between bilateral trust and international trade, GSZ instrument the endogenous variable with a proxy of religious similarity and an indicator of somatic distance which measures the distance between three anthropometric characteristics observed in the native populations of two countries: the average height, the prevailing hair color, and the average cephalic index, which measures the average width and length of an individual's skull. In an experiment, DeBruine (2002) finds that people trust other people who resemble themselves significantly more. We hence expect a decrease in somatic distance to increase international trade through its positive effect on bilateral trust. The second instrument, religious similarity, measures the probability that a randomly picked individual in country $d$ has the same religion as a randomly picked individual in country $s$. As religion may shape beliefs, it may positively affect bilateral trust. However, we suspect religious similarity to capture also other cultural and institutional variables that foster international trade. If religious similarity does not satisfy the exclusion restrictions, i.e. if it affects the dependent variables other than through bilateral trust, then it is not a valid instrumental variable and must be included as a control variable in the trade regression. We therefore also estimate alternative specifications in which the vector $\mathbf{X}_{s d}^{\prime}$ contains the measure of religious similarity. In these cases, bilateral trust is instrumented only with an indicator of somatic distance.

When estimating the trade equations, we compute standard errors that are robust to heteroskedasticity of unknown and arbitrary form. Moreover, we cluster at the countrypair which allows the standard errors to be correlated over time within country-pairs, but assumes that they are uncorrelated with errors of a different country-pair. The data used to analyze equation (1) is described next. 


\subsection{Data}

The aggregated commodity export flows are collected by the International Merchandise Trade Statistics Section (IMTS) of the United Nations Statistics Division. It standardizes data delivered by national statistical authorities and continuously updates the UN Comtrade Database which contains detailed statistics on the import and export of commodities for over 250 countries and areas. ${ }^{8}$ These aggregated commodity export flows are regressed on DtS trust, an indicator proposed by the Eurobarometer Surveys. These surveys are mandated by the European Commission in order to have a better understanding of the public opinion in the European Member States. To reach this objective, approximately 1,000 individuals per Member State are interviewed yearly since 1970 using a common questionnaire. The question of interest for our paper is: " $I$ would like to ask you a question about how much trust you have in people from various countries. For each, please tell me whether you have a lot of trust, some trust, not very much trust, or no trust at all." It was first asked in the year 1970 in five European countries. From 1970 to 1996, it reappeared ten times in the standard Eurobarometer Surveys and the country sample increased each time. ${ }^{9}$ In 1996, citizens of 17 European countries were asked to indicate the trust they had towards citizens of $25 \mathrm{EU}$ and Non-EU countries. For reasons of homogeneity, we follow GSZ and focus on European countries only. We construct the bilateral trust indicator analogously to GSZ by coding the answers to this question the following way: 1 (no trust at all), 2 (not very much trust), 3 (some trust), 4 (a lot of trust). In a next step, we compute the average level of bilateral trust for each country-pair by taking the mean value of the answers in each year for which we have survey data.

The dyadic dummy variables included in equation (1) come from the CEPII Grav-

\footnotetext{
${ }^{8}$ In the UN Comtrade Database, the commodities are classified according to the Standard International Trade Classification (SITC), the Harmonized Commodity Coding System (HS), and The Broad Economic Categories (BEC). The data can be downloaded from http://comtrade.un.org/db/default.aspx. Unfortunately, we cannot include data on trade in services as this data is only collected since the year 2000 .

${ }^{9}$ The data can be downloaded from the ZACAT-GESIS Online Study catalogue, http://zacat.gesis.org/webview/. The bilateral trust question was asked in the Eurobarometer Survey of the years 1970, 1976, 1980, 1983, 1986, 1990, 1991, 1993, 1994, and 1996.
} 
ity Dataset generated by Head, Mayer and Ries $(2010,2013) .{ }^{10}$ The measure of geographical distance between countries was established by Mayer and Zignago (2011). ${ }^{11}$ As proxy for trade costs, GSZ use the indicator for geographical distance proposed by Frankel, Stein, and Wei (1995) which measures the (log) distance in kilometers between two capital cities. It assumes that the whole population is concentrated in one geographical point, thereby failing to capture the distribution of economic activity within a country. Head and Mayer (2002) argue that the inclusion of this distance measures in a gravity-type equation systematically inflates the estimated border effect because it overestimates the geographical distances within a country relative to international distances. Therefore, we only use it to replicate the results of GSZ. In the rest of the paper, we focus on the population-weighted distance indicator provided by Mayer and Zignago (2011), which calculates the "distances between two countries based on bilateral distances between the biggest cities of those two countries, those inter-city distances being weighted by the share of the city in the overall country's population" (p. 11).

GSZ provided us with their indicator of press coverage ${ }^{12}$ and we reconstruct the proxies for transportation costs and for linguistic common roots following the instructions given by GSZ. As proxy for transportation costs we use the estimates for shipping costs made available on line by the Import Export Wizard. ${ }^{13}$ The data employed to compute the commonality of two official languages comes from "The Ethnologue". ${ }^{14}$

The indicator of somatic distance used as an instrumental variable for bilateral

\footnotetext{
${ }^{10}$ It can be downloaded from www.cepii.fr.

${ }^{11}$ See http://www.cepii.fr/CEPII/fr/bdd_modele/presentation.asp?id=6.

${ }^{12}$ As outlined by GSZ (p. 1106), the measure of press coverage was established in the following way: "In Factiva, we searched the newspaper with the highest circulation for each country. For each pair of countries $i$ and $j$, we recorded the number of articles in the newspaper of countries that mentioned country $j$ or its citizens in the headline. We divided this number by the number of total news stories on foreign countries". Factiva is an online research tool owned by Dow Jones \& Company. It collects and archives informations made available by over 30'000 newspapers, journals, magazines, web pages, etc. on a broad range of contents. It aggregates information from over 200 countries. See www.factiva.com.

${ }^{13}$ The Import-Export Wizard is a Internet page which estimate the price of shipping or flying a good from one country to another. We downloaded the prices of shipping a $1.000 \mathrm{~kg}$ unspecified freight type load with no special handling in June 2011. See http://importexportwizard.com. GSZ based this measure on Giuliano, Spilimbergo, and Tonon (2006).

${ }^{14}$ See www.ethnologue.com and the printed version edited by Lewis et al. (2013).
} 
trust can be constructed in many different ways. Four measures are made available in the online-appendix to the paper by GSZ (Guiso et al., 2008a). ${ }^{15}$ They are constructed based on four anthropometric indicators: hair color, cephalic index, height, and skin color. The first three anthropometric indicators were published by Biasutti (1959). He classifies the world into five categories of hair colors: 1 (blond prevails), 2 (mix of blond and dark), 3 (dark prevails), 4 (sporadic presence of blond), and 5 (exclusively dark). He further differentiates five categories of average cephalic indexes, going from 71.0 to $86+$, and six categories of height. For illustration, Figure 1 reprints the distribution of the average cephalic index for European regions.

Using today's borders, many countries fall into several classes of these traits, in which case GSZ focus on the predominant category and ignore the others. They attribute scores to the different groups of hair color, cephalic index, height, and skin color, and "compute the somatic distance between two countries as the sum of the absolute value of the difference in each of these traits" (GSZ, p. 1107). Their constructed four measures of somatic distance are all computed in the same fashion but they are based on different combinations of these four physical characteristics. One measure of somatic distance sums the absolute distance in all four dimensions. The sole measure used in the study of GSZ ignores the difference in skin color. A third measure is based on differences in hair color, height, and skin color. Finally, another measure only sums the absolute differences in hair color and height.

We construct four additional measures of somatic distance. To do this, we attribute the score of 1 to the category corresponding to the lowest average cephalic index (71.0 - 74.9), 2 to the second category $(75.0$ - 78.9), and so on. The six categories of height defined by Biasutti (1959) are coded the same way, attributing the lowest score of 1 to the category "157.9 cm or less" and the highest score of 6 to "178 $\mathrm{cm}$ or more". In a first step, we follow exactly the instructions given by Guiso et al. (2008a, p. 3 ) and try to replicate the single measure of somatic distance used in GSZ. As it is hardest to define which category of cephalic index prevails, our second measure is

\footnotetext{
${ }^{15}$ These measures can be downloaded from Paola Sapienza's web page under http://www.kellogg.northwestern.edu/faculty/sapienza/htm/somaticdistance.zip.
} 
Figure 1

Distribution of the Average Cephalic Index in Europe

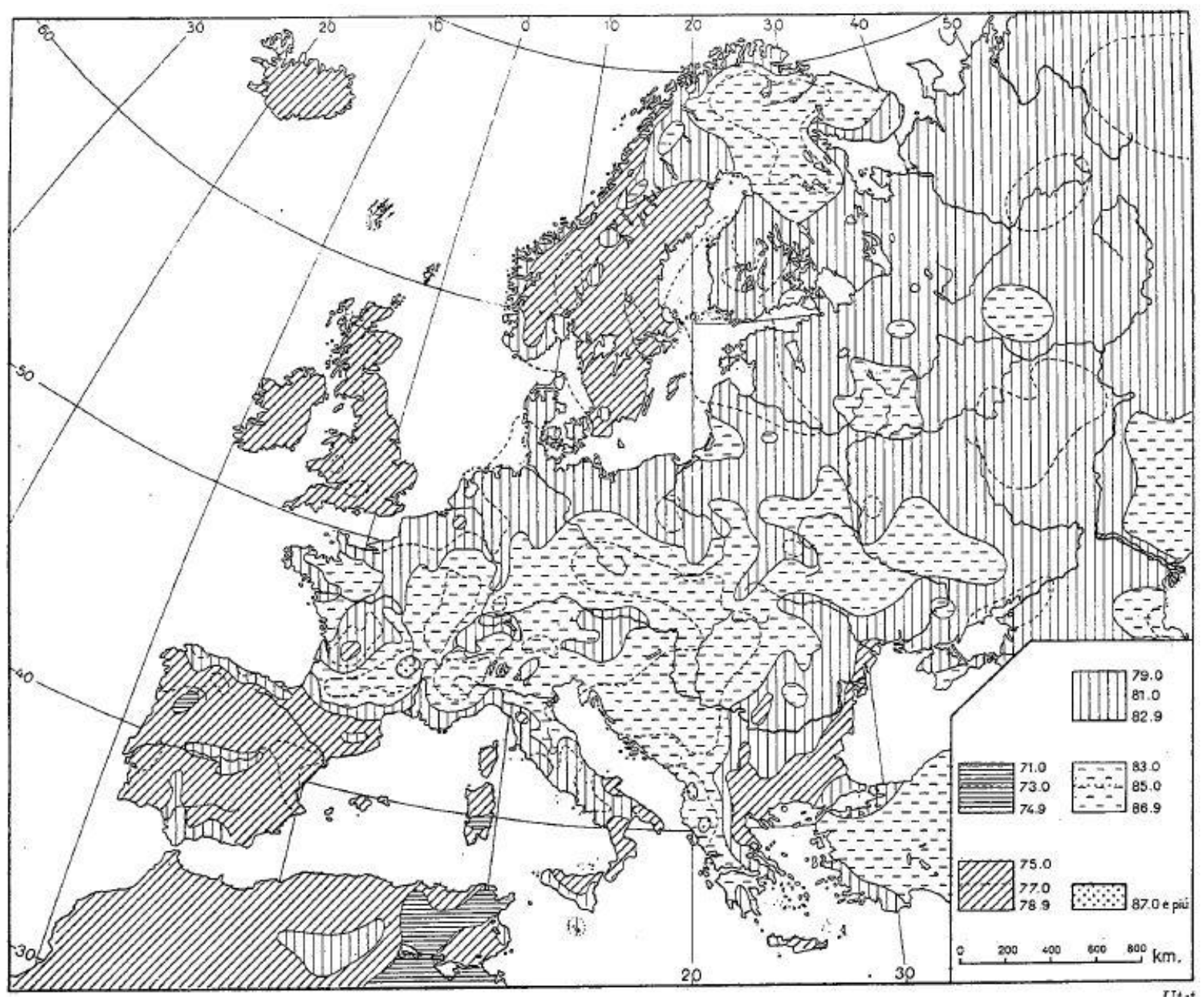

Source : Biasutti, R. (1959), p. 48 
based only on the absolute differences in hair color and height. The next two measures differ from the others by allowing a country to fall into two categories and weight them according to population density. ${ }^{16}$ One measure is again based on the three anthropometric indicators proposed by Biasutti while the other ignores the differences in cephalic index. The data on population density comes from two figures: a map with the population density in 1989 provided by the European Environment Agency and one with the population density in 2010 made available by the Nordic Center for Spatial Development. ${ }^{17}$

The indicator of religious similarity used to capture the exogenous part of bilateral trust is constructed with data from the World Value Surveys presented by Guiso et al. (2003). They report the national distribution of population by the following religious affiliation: Catholic, Protestant, Jewish, Muslim, Hindu, Buddhist, no religious affiliation and other affiliations. We use this information to compute the probability that two randomly picked individuals in two different countries have the same religion.

The descriptive statistics of the samples used to analyze the relationship between international trade and DtS trust are presented in Panel A of Table $1 .^{18}$

\footnotetext{
${ }^{16}$ For some countries, we find it very difficult to decide which trait is prevailing, especially when focusing on the different categories of cephalic index. For example, in Figure 1 we see that northern Germany falls into category 3, "79.0 - 82.9", while the other half of Germany falls into category 4, "83.0 - 86.9". Guiso et al. (2008a) do not indicate how they decide which one of these categories prevails in such situations. We partially succeed to replicate their somatic distances when we decide visually (based on Figure 1) which trait covers a larger area and assume that it is the dominant characteristic. However, this procedure is somewhat arbitrary, especially when ignoring the distribution of the population. As the German population is approximately equally distributed, we would ignore the characteristics of half of the population if we arbitrarily decided that either category 3 or 4 prevails. To account for this, our two measures of somatic distance allow a country to be home of two categories of traits, depending on the distribution of the population. Concretely, in the case of Germany we find that the categories of cephalic index 3 ("79.0 - 82.9") and 4 ("83.0 - 86.9") roughly share the German territory and population. Therefore, we decide to attribute it the score of 3.5. This measure is certainly not flawless but it allows us to further explore the robustness of the results published by GSZ.

${ }^{17}$ See Stanners, D. and Bourdeau, Ph. (1994) or www.eea.europa.eu/publications/92-8275122-8/page008.html for the chart on population density in 1989 and Roto, J. (2011) or www.nordregio.se/en/Maps-graphs/ for the population density in 2010.

${ }^{18}$ We follow GSZ by only including observations for countries that were members of the European Economic Area before 1997 and for Norway.
} 


\begin{tabular}{|c|c|c|c|c|c|c|}
\hline Variable & Mean & Median & Std. dev. & Min & Max & $\mathrm{N}$ \\
\hline \multicolumn{7}{|c|}{ Panel A International Trade and Destination-to-Source Trust } \\
\hline Export flows (from source to destination, log) & 14.56 & 14.63 & 1.64 & 9.57 & 17.88 & 679 \\
\hline DtS Trust & 2.73 & 2.72 & 0.28 & 1.99 & 3.65 & 679 \\
\hline Press Coverage & 0.04 & 0.02 & 0.05 & 0.00 & 0.31 & 679 \\
\hline Weighted Distance (log) & 7.00 & 7.06 & 0.55 & 5.08 & 8.13 & 679 \\
\hline Distance between capitals (log) & 6.90 & 7.07 & 0.69 & 5.15 & 8.12 & 679 \\
\hline Transportation costs (log) & 5.19 & 5.18 & 0.07 & 5.08 & 5.42 & 679 \\
\hline Common border & 0.20 & 0.00 & 0.40 & 0.00 & 1.00 & 679 \\
\hline Common language & 0.08 & 0.00 & 0.28 & 0.00 & 1.00 & 679 \\
\hline Same legal origin & 0.31 & 0.00 & 0.46 & 0.00 & 1.00 & 679 \\
\hline Linguistic common roots & 0.63 & 0.67 & 0.20 & 0.00 & 1.00 & 679 \\
\hline Religious similarity & 0.34 & 0.33 & 0.25 & 0.00 & 0.87 & 679 \\
\hline \multicolumn{7}{|l|}{ Somatic Distance } \\
\hline \multicolumn{7}{|c|}{ Available in Guiso et al. (2008a), sum of the absolute differences in the following prevailing traits } \\
\hline - hair color, height, cephalic index, skin & 2.93 & 3.00 & 1.37 & 0.00 & 6.00 & 679 \\
\hline - hair color, height, skin & 2.05 & 2.00 & 1.29 & 0.00 & 5.00 & 679 \\
\hline - hair color, height, cephalic index & 2.48 & 2.00 & 1.20 & 0.00 & 5.00 & 679 \\
\hline - hair color, height & 1.60 & 2.00 & 1.08 & 0.00 & 4.00 & 679 \\
\hline \multicolumn{7}{|c|}{ Own elaboration, following the instructions in Guiso et al. (2008a) } \\
\hline - hair color, height, cephalic index & 2.35 & 2.00 & 1.21 & 0.00 & 5.00 & 679 \\
\hline - hair color, height & 1.48 & 2.00 & 0.96 & 0.00 & 3.00 & 679 \\
\hline \multicolumn{7}{|c|}{ Own elaboration, allowing for a country to fall into two categories of } \\
\hline - hair color, height, cephalic index & 2.15 & 2.00 & 1.15 & 0.00 & 4.50 & 679 \\
\hline - hair color, height & 1.47 & 1.50 & 1.04 & 0.00 & 3.00 & 679 \\
\hline \multicolumn{7}{|c|}{ Panel B International Migration and Source-to-Destination Trust } \\
\hline Gross Immigraiton Flows (log) & 6.84 & 6.84 & 1.87 & 2.08 & 12.13 & 450 \\
\hline StD Trust & 2.79 & 2.79 & 0.30 & 1.99 & 3.65 & 450 \\
\hline Diff. in GDP p.c. (\%) & 0.34 & 0.18 & 0.66 & -0.62 & 3.55 & 450 \\
\hline Common language & 0.09 & 0.00 & 0.28 & 0.00 & 1.00 & 450 \\
\hline Weighted Distance (log) & 6.91 & 7.01 & 0.62 & 5.08 & 8.13 & 450 \\
\hline Common border & 0.21 & 0.00 & 0.41 & 0.00 & 1.00 & 450 \\
\hline Same legal origin & 0.32 & 0.00 & 0.47 & 0.00 & 1.00 & 450 \\
\hline Migration Stock $1960(\log )$ & 4.86 & 0.00 & 5.56 & 0.00 & 13.50 & 450 \\
\hline Religious similarity & 0.31 & 0.32 & 0.24 & 0.00 & 0.87 & 450 \\
\hline \multicolumn{7}{|l|}{ Somatic Distance } \\
\hline \multicolumn{7}{|c|}{ Available from Guiso et al. (2008a), sum of the absolute differences in the following prevailing traits } \\
\hline - hair color, height, cephalic index, skin & 2.87 & 3.00 & 1.40 & 0.00 & 6.00 & 450 \\
\hline - hair color, height, skin & 2.11 & 2.00 & 1.34 & 0.00 & 5.00 & 450 \\
\hline - hair color, height, cephalic index & 2.43 & 3.00 & 1.18 & 0.00 & 5.00 & 450 \\
\hline - hair color, height & 1.67 & 2.00 & 1.09 & 0.00 & 4.00 & 450 \\
\hline \multicolumn{7}{|c|}{ Own elaboration, following the instructions in Guiso et al. (2008a) } \\
\hline - hair color, height, cephalic index & 2.35 & 2.00 & 1.20 & 0.00 & 5.00 & 450 \\
\hline - hair color, height & 1.56 & 2.00 & 0.97 & 0.00 & 3.00 & 450 \\
\hline \multicolumn{7}{|c|}{ Own elaboration, allowing for a country to fall into two categories of } \\
\hline - hair color, height, cephalic index & 2.10 & 2.00 & 1.13 & 0.00 & 4.50 & 450 \\
\hline - hair color, height & 1.51 & 1.50 & 1.03 & 0.00 & 3.00 & 450 \\
\hline
\end{tabular}




\begin{tabular}{|c|c|c|c|c|c|c|}
\hline Variable & Mean & Median & Std. dev. & Min & Max & $\mathrm{N}$ \\
\hline \multicolumn{7}{|c|}{ Panel C International Migration and Destination-to-Source Trust } \\
\hline Gross Immigraiton Flows (log) & 6.84 & 6.82 & 1.87 & 2.08 & 12.13 & 463 \\
\hline DtS Trust & 2.76 & 2.75 & 0.30 & 2.04 & 3.65 & 463 \\
\hline Diff. in GDP p.c. (\%) & 0.38 & 0.19 & 0.70 & -0.62 & 3.55 & 463 \\
\hline Common language & 0.09 & 0.00 & 0.28 & 0.00 & 1.00 & 463 \\
\hline Weighted Distance (log) & 6.91 & 7.01 & 0.62 & 5.08 & 8.13 & 463 \\
\hline Common border & 0.21 & 0.00 & 0.40 & 0.00 & 1.00 & 463 \\
\hline Same legal origin & 0.33 & 0.00 & 0.47 & 0.00 & 1.00 & 463 \\
\hline Migration Stock 1960 (log) & 5.04 & 0.00 & 5.57 & 0.00 & 13.50 & 463 \\
\hline Religious similarity & 0.32 & 0.32 & 0.24 & 0.00 & 0.87 & 463 \\
\hline \multicolumn{7}{|l|}{ Somatic Distance } \\
\hline \multicolumn{7}{|c|}{ Available from Guiso et al. (2008a), sum of the absolute differences in the following prevailing traits } \\
\hline - hair color, height, cephalic index, skin & 2.88 & 3.00 & 1.40 & 0.00 & 6.00 & 463 \\
\hline - hair color, height, skin & 2.12 & 2.00 & 1.34 & 0.00 & 5.00 & 463 \\
\hline - hair color, height, cephalic index & 2.44 & 3.00 & 1.19 & 0.00 & 5.00 & 463 \\
\hline - hair color, height & 1.68 & 2.00 & 1.09 & 0.00 & 4.00 & 463 \\
\hline \multicolumn{7}{|c|}{ Own elaboration, following the instructions in Guiso et al. (2008a) } \\
\hline - hair color, height, cephalic index & 2.37 & 2.00 & 1.20 & 0.00 & 5.00 & 463 \\
\hline - hair color, height & 1.57 & 2.00 & 0.97 & 0.00 & 3.00 & 463 \\
\hline \multicolumn{7}{|c|}{ Own elaboration, allowing for a country to fall into two categories of } \\
\hline - hair color, height, cephalic index & 2.11 & 2.00 & 1.14 & 0.00 & 4.50 & 463 \\
\hline - hair color, height & 1.52 & 1.50 & 1.03 & 0.00 & 3.00 & 463 \\
\hline
\end{tabular}

Notes. This table presents the descriptive statistics of the sample used to estimate the effect of DtS trust on commodity export flows (Panel A), the impact of StD trust on gross immigration flows (Panel B), and the effect of DtS trust on gross immigration flows (Panel C). The data sources are described in sections 2.2 and 3. All samples include observations for European countries over the years for which we have trust data (1970, 1976, 1980, 1983, 1986, 1990, 1991, 1993, 1994, and 1996). The number of observations varies across the panels because of missing data. 


\subsection{Results}

Table 2 present the result of estimating equation (1). In Panel A, we use a similar indicator of geographical distance between countries as GSZ (distance between two capital cities). In this case, we find coefficients on bilateral trust that are very similar to the ones published in their study. ${ }^{19}$ The coefficient on geographical distance is barely significant, however. Yet, as discussed in section 2.2, we suspect this measure to be inadequate and we therefore replace it by the outlined population-weighted distance indicator in Panel B. The coefficient on bilateral distances now becomes significant and has a point-estimate close to -1 which corresponds to the magnitude generally estimated in trade regressions that are based on the gravity model (Meyer and Zignago, 2011, p. 11). We also observe that the estimated border effect decreases compared to Panel A, supporting the conjecture made by Head and Mayer (2002) that measuring geographical distance by the distance between capital cities inflates the border effect. More importantly, we find that, when including a weighted measure of distance in the specification, the point estimates of the coefficients on DtS trust decrease. In fact, the positive OLS estimates reported in columns (1) to (3) of Panel B are insignificant.

Next, we apply the IV approach proposed by GSZ as DtS trust seems to be correlated with the error term. ${ }^{20}$ When instrumented with both the measure of religious similarity and the measure of somatic distance used in GSZ, the coefficient on DtS trust becomes significant at the 5 percent level (column (4)). ${ }^{21}$ It suggests that an increase in DtS trust of one standard deviation increases aggregated commodity export flows on average by 24 percent which is more than six times the effect predicted by the OLS estimate. This large jump might simply reflect the fact that we accounted for endogeneity bias. However, we need to examine the validity of the applied IV approach before concluding that it represents the true causal relationship of interest. In fact,

\footnotetext{
${ }^{19}$ Compare to Table IV in GSZ (pp. 1116f).

${ }^{20}$ We verify the endogeneity of bilateral trust with a control function approach (see Wooldridge, 2010, p. 127) and perform an endogeneity test that is robust to arbitrary heteroskedasticity, following Baum, Schaffer and Stillman (2007). Both tests allow us to reject the null hypothesis at conventional levels which states that bilateral trust is exogenous.

${ }^{21}$ This IV approach reports the efficient generalized method of moments (GMM) estimates and the cluster-robust standard errors.
} 
Table 2

Trade Regression

\begin{tabular}{|c|c|c|c|c|c|c|}
\hline & $\begin{array}{c}\text { OLS } \\
(1) \\
\end{array}$ & $\begin{array}{c}\text { OLS } \\
(2)\end{array}$ & $\begin{array}{c}\text { OLS } \\
(3)\end{array}$ & $\begin{array}{c}\text { IV-SR } \\
(4)\end{array}$ & $\begin{array}{c}\text { IV-S } \\
(5)\end{array}$ & $\begin{array}{c}\text { OLS-RF } \\
(6)\end{array}$ \\
\hline \multicolumn{7}{|c|}{ Panel A: Distance between Capital Cities } \\
\hline DtS trust & $\begin{array}{l}0.37 * \\
(0.21)\end{array}$ & $\begin{array}{c}0.29 \\
(0.20)\end{array}$ & $\begin{array}{c}0.28 \\
(0.20)\end{array}$ & $\begin{array}{c}1.27 * * * \\
(0.38)\end{array}$ & $\begin{array}{c}1.50 * * * \\
(0.50)\end{array}$ & \\
\hline Common language & $\begin{array}{c}0.45^{* *} * \\
(0.21)\end{array}$ & $\begin{array}{c}0.26 \\
(0.16)\end{array}$ & $\begin{array}{c}0.25 \\
(0.17)\end{array}$ & $\begin{array}{c}0.15 \\
(0.15)\end{array}$ & $\begin{array}{c}0.17 \\
(0.15)\end{array}$ & $\begin{array}{l}0.30 * \\
(0.16)\end{array}$ \\
\hline Distance between capitals (log) & $\begin{array}{l}-0.05 \\
(0.19)\end{array}$ & $\begin{array}{c}-0.26 \\
(0.18)\end{array}$ & $\begin{array}{l}-0.24 \\
(0.18)\end{array}$ & $\begin{array}{l}-0.32 * \\
(0.16)\end{array}$ & $\begin{array}{l}-0.30 * \\
(0.17)\end{array}$ & $\begin{array}{l}-0.22 \\
(0.17)\end{array}$ \\
\hline Common border & $\begin{array}{c}0.49 * * * \\
(0.14)\end{array}$ & $\begin{array}{c}0.42 * * * \\
(0.12)\end{array}$ & $\begin{array}{c}0.41 * * * \\
(0.12)\end{array}$ & $\begin{array}{c}0.37 * * * \\
(0.12)\end{array}$ & $\begin{array}{c}0.38 * * * \\
(0.12)\end{array}$ & $\begin{array}{c}0.34 * * * \\
(0.12)\end{array}$ \\
\hline Press coverage & $\begin{array}{c}1.37 \\
(1.12)\end{array}$ & $\begin{array}{c}0.57 \\
(1.11)\end{array}$ & $\begin{array}{c}0.66 \\
(1.12)\end{array}$ & $\begin{array}{c}1.57 \\
(0.96)\end{array}$ & $\begin{array}{c}1.21 \\
(1.05)\end{array}$ & $\begin{array}{c}0.81 \\
(1.17)\end{array}$ \\
\hline Transportation costs (log) & $\begin{array}{c}-4.41 * * \\
(1.97)\end{array}$ & $\begin{array}{l}-1.82 \\
(1.90)\end{array}$ & $\begin{array}{l}-1.82 \\
(1.85)\end{array}$ & $\begin{array}{l}-0.09 \\
(1.65)\end{array}$ & $\begin{array}{l}-0.43 \\
(1.72)\end{array}$ & $\begin{array}{l}-1.43 \\
(1.82)\end{array}$ \\
\hline Same legal origin & & $\begin{array}{c}0.45^{* * * *} \\
(0.14)\end{array}$ & $\begin{array}{c}0.39 * * \\
(0.15)\end{array}$ & $\begin{array}{c}0.32 * * \\
(0.14)\end{array}$ & $\begin{array}{c}0.38^{* * *} \\
(0.16)\end{array}$ & $\begin{array}{c}0.34^{* *} \\
(0.15)\end{array}$ \\
\hline Linguistic common roots & & & $\begin{array}{c}0.25 \\
(0.31)\end{array}$ & $\begin{array}{c}0.17 \\
(0.27)\end{array}$ & $\begin{array}{c}0.11 \\
(0.29)\end{array}$ & $\begin{array}{c}0.12 \\
(0.30)\end{array}$ \\
\hline Religious similarity & & & & & $\begin{array}{l}-0.19 \\
(0.22)\end{array}$ & $\begin{array}{c}0.05 \\
(0.16)\end{array}$ \\
\hline Somatic Distance used in GSZ & & & & & & $\begin{array}{c}-0.09 * * * \\
(0.03)\end{array}$ \\
\hline $\begin{array}{l}\text { Relevance } \\
\text { K-P rk LM Statistic } \\
\text { (p-value) }\end{array}$ & & & & $\begin{array}{l}17.91 \\
(0.00)\end{array}$ & $\begin{array}{c}16.5 \\
(0.00)\end{array}$ & \\
\hline $\begin{array}{l}\text { Weak Identification } \\
\text { K-P rk Wald Statistic }\end{array}$ & & & & 17.05 & 26.03 & \\
\hline $\begin{array}{l}\text { Over-identification } \\
\text { Hansen } J \text {-Stat } \\
\text { (p-value) }\end{array}$ & & & & $\begin{array}{l}0.780 \\
(0.38) \\
\end{array}$ & & \\
\hline
\end{tabular}

Panel B: Population-Weighted Distance Measure

DtS trust

Common language

Weighted Distance (log)

Common border

Press coverage

Transportation costs (log)

Same legal origin

Linguistic common roots

Religious similarity

Somatic Distance used in GSZ

Relevance

K-P rk LM Statistic

(p-value)

Weak Identification

K-P rk Wald Statistic

Over-identification

Hansen $J$-Stat

(p-value)

Observations

R-squared

$\begin{array}{cc}0.27 & 0.13 \\ (0.18) & (0.17) \\ 0.38 * * & 0.24 * * \\ (0.16) & (0.11) \\ -0.88 * * * & -1.03 * * * \\ (0.25) & (0.22) \\ 0.29 * * * & 0.24 * * \\ (0.11) & (0.10) \\ 0.13 & -1.01 \\ (1.05) & (0.95) \\ 0.42 & 2.27 \\ (1.91) & (1.66) \\ & 0.45 * * *\end{array}$

(0.10)

$\begin{array}{cc}0.13 & 0.85 * * \\ (0.17) & (0.35) \\ 0.25 * * & 0.25 * * \\ (0.12) & (0.10) \\ -1.04 * * * & -0.94 * * * \\ (0.23) & (0.24) \\ 0.24 * * & 0.25 * * * \\ (0.10) & (0.09) \\ -1.06 & -0.34 \\ (0.96) & (0.89) \\ 2.31 & 2.48 \\ (1.68) & (1.57) \\ 0.47 * * * & 0.41 * * * \\ (0.13) & (0.13) \\ -0.07 & -0.11 \\ (0.32) & (0.28)\end{array}$

(0.28)
$0.96 * *$

(0.47)

$0.24 * *$

(0.10)

$0.30 * *$

(0.12)

$-0.91 * * *$

(0.25)

$-0.99 * * *$

(0.23)

$0.21 * *$

$0.26 * * *$

(0.10)

(0.10)

$-0.80$

(0.98)

2.49

(1.66)

$0.42 * * *$

(0.13)

$-0.15$

(0.31)

0.11

(0.14)

$-0.06^{*}$

(0.03)

$\begin{array}{ll}16.95 & 14.65 \\ (0.00) & (0.00) \\ & \\ 16.93 & 22.99 \\ & \\ 0.13 & \\ (0.72) & \end{array}$

679

679

679

0.97

Notes. The dependent variable is the natural logarithm of aggregated export flows from country $s$ to country $d$ (UNComtrade). DtS Trust measures the average trust that citizens in importing country $d$ grant citizens in exporting country $s$ (Eurobarometer Surveys). Somatic distance is the measure used in GSZ which sums the absolut value of the difference in the hair color, height, and cephalic index. All equations include countr-year dummies. The Kleibergen-Paap $r k$ LM and Wald statistics are the robust statistics in case of non-i.i.d. disturbances. Robust standard errors are reported in parentheses, that are clustered at the country-pair. Coefficients are statistically different from zero at the ***1\%,**5\%, and *10\% level. Columns (1) to (3) present OLS estimates; columns (4) and (5) present IV/GMM estimates with somatic distance and religious similarity as instruments (IV-SR) and with somatic distance as only instrument (IV-S), respectively. RF (column (6)) refers to the reduced form of the dependent variable (see appendix). 
both measures of cultural proximity of country-pairs are significant in the first-stage regression. Bilateral trust seems to increase with religious similarity and decrease when physical dissimilarities between two countries become more important. The $p$-value of the Kleibergen-Paap $r k$ LM Statistic also suggests that the instruments are jointly significant in the first stage of the 2SLS regression. ${ }^{22}$ In addition, the Wald statistic based on the Kleinbergen-Paap $r k$ statistic is larger than 10, indicating a sufficiently "strong" correlation between the instruments and DtS trust in order not to worry about weak identification problems. ${ }^{23}$ Finally, the instruments pass the Hansen $J$-test intended to verify their exogeneity, i.e. that the instruments only affect the dependent variable through the trust channel.

The standard statistical tests hence suggest that the IV strategy used by GSZ is valid. Nevertheless, we suspect religious similarity to affect international trade also through other channels than bilateral trust. This sheds doubts on the results presented in column (4) and also on the over-identification test, as the latter is only reliable when the instruments are valid (Murray, 2006). Therefore, we estimate an alternative specification which includes religious similarity as a covariate and where the exogenous variation of bilateral trust is captured with a single instrument, the indicator of somatic distance used in GSZ. The results of estimating this specification are presented in column (5). The coefficient on DtS trust slightly increases and the significance is unchanged, compared to column (4).

We further estimate the corresponding reduced-form equation of the dependent variable. This equation is "derived by substituting the first-stage equation into the

\footnotetext{
${ }^{22}$ The Kleibergen-Paap $r k$ LM Statistic is the efficient first-stage statistic used to verify the relevance of the instruments when non-i.i.d. disturbances are assumed. Rejection of the null hypothesis suggest that the model is identified, i.e. that the instruments are relevant.

${ }^{23}$ In the presence of i.i.d. disturbances, weak identification problems are detected with the CraggDonald $F$-statistic which is compared to the critical values published by Stock and Yogo (2005). However, in case of non-i.i.d. disturbances, the Kleinbergen-Paap $r k$ Wald statistic is the efficient statistic (Kleibergen and Paap, 2006; Kleibergen and Schaffer, 2007; Baum, 2007). So far, no critical values have been computed for this statistic and in practice it is usually compared to the threshold number of 10 recommended by Staiger and Stock (1997); see also Stock, Wright and Yogo (2002). As a robustness test, we compute the limited information maximum likelihood (LIML) estimates of all our 2SLS regressions and find that the bilateral trust coefficients only slightly change in their size and that the levels of statistical significance are identical to the IV/GMM estimates. The results of this robustness analysis are available in an online appendix (Tables A.1 - A.3).
} 
causal relation of interest" (Angrist and Pischke, 2009, p. 121). ${ }^{24}$ The first-stage regression is

$$
\text { trust }_{d s, t}=\delta_{0}+\delta_{1} S_{d s}+\mathbf{X}_{s d}^{\prime} \eta+\lambda_{s, t}+\lambda_{d, t}+u_{s d, t},
$$

where $S_{d s}$ is the indicator of somatic distance between country $d$ and country $s$, and $\mathbf{X}_{s d}^{\prime}$ contains all time-invariant bilateral exogenous covariates including the proxy for religious similarity. Substituting (2) into (1) and rearranging terms we find

$$
\begin{aligned}
\log \left(\text { export }_{s d, t}\right)= & \left(\beta_{0}+\beta_{1} \delta_{0}\right)+\beta_{1} \delta_{1} S_{d s}+\left(\beta_{1} \eta+\gamma\right) \mathbf{X}_{s d}^{\prime}+\left(\beta_{1}+1\right) \lambda_{s, t}+ \\
& \left(\beta_{1}+1\right) \lambda_{d, t}+\left(\beta_{1} u_{s d, t}+\epsilon_{s d, t}\right) \\
\equiv & \tau_{0}+\tau_{1} S_{d s}+\mathbf{X}_{s d}^{\prime} \phi+\hat{\lambda}_{s, t}+\hat{\lambda}_{d, t}+v_{s d, t} .
\end{aligned}
$$

$\hat{\lambda}_{s, t}$ and $\hat{\lambda}_{d, t}$ are time varying national dummies, and $v_{s d, t}$ is the error term. If the exclusion restriction is satisfied, then, by assumption, all variables in equation (3) are orthogonal to the error term $v_{s d, t}$. This implies that OLS consistently estimates the coefficients and that testing whether $\tau_{1} \equiv \beta_{1} \delta_{1}=0$ is an alternative way of testing the hypothesis that $\beta_{1}=0$ in equation (1). As Angrist and Pischke (2009, p. 213) point out, "if you can't see the causal relation of interest in the reduced form, it's probably not there". Column (6) reports the results of estimating the reduced-form equation (3). As expected from the second-stage results, we see that the coefficient on somatic distance is significant, though only at the 10 percent level. Furthermore, religious similarity is not correlated with international trade, a finding which comforts us in our decision to estimate an alternative specification that includes the proxy for religious similarity as control variable.

The disadvantage of instrumenting DtS trust with a single instrument is that we have no means to statistically verify its exogeneity anymore. In such situations, Murray (2006) proposes to estimate the regression of interest again, using separately alternative

\footnotetext{
${ }^{24}$ See Anderson and Rubin (1949), Dufour (2003), and Chernozhukov and Hansen (2008) for a formal explanation of this alternative test and Angrist and Krueger (1991, 2001) for an application of this method. See also Baum et al. (2007) for an implementation of the Anderson-Rubin test in Stata. This test verifies whether the instruments are significant in the reduced form equation of the dependent variable.
} 
instruments and to observe how the coefficient on the endogenous variable behaves. If this procedure yields estimates that only vary insignificantly from one another, then the credibility of the instrumental variable is strengthened. Such a sensitivity analysis can be performed here as there is a large degree of freedom in constructing a measure of somatic distance. The different indicators of somatic distance described in section 2.2 all capture the physical dissimilarities between two countries and are constructed in a similar fashion. It should therefore not matter for consistent results which one of them is used to capture the exogenous variation of bilateral trust. To examine the robustness of the results reported in Table 2, we hence estimate equation (1) again, keeping the same sample and the same explanatory variables. We vary, however, the measure of somatic distance that we use as instrument for DtS trust. The results of this sensitivity analysis are reported in Table $3 .^{25}$

Table 3 is divided in four panels. Panel A reports the results of estimating the first-stage regression and Panel B of estimating the reduced-form equation (3). The IV coefficients without and with religious similarity as explanatory variable are presented in Panel C and Panel D, respectively. Each panel is composed of eight columns which differ in the indicator of somatic distance employed as instrument for DtS trust. We start with the four indicators made available by Guiso et. al (2008a). Columns (1) of Panel B, C and D restate the most important results presented in Table 2 (columns (6), (4) and (5), respectively), where we employ the somatic distance measure actually used in GSZ, i.e. the sum of the absolute values of the difference in hair color, height, and cephalic index (HHC) of two average citizens living in distinct countries. Column (2) is based on a somatic distance measure that additionally considers the differences in the skin color (HHCS). For column (3), the differences in the cephalic index (HHS) are ignored. The measure used for column (4) sums the absolute differences in hair color and height (HH). For columns (5) and (6), we use the measures of somatic distance that we constructed ourselves following the instructions given in Guiso et al. (2008a),

\footnotetext{
${ }^{25}$ We only report the coefficients on DtS trust, somatic distance, and religious similarity. Complete tables including the estimates of the coefficients on the control variables are available in an online appendix (Tables B.1 - B.3).
} 
Table 3

Trade Regression: Instrumenting DtS Trust with Alternative Measures of Somatic Distance

\begin{tabular}{|c|c|c|c|c|c|c|c|c|}
\hline & \multicolumn{4}{|c|}{ Guiso et al. (2008a) } & \multicolumn{2}{|c|}{ Replication } & \multicolumn{2}{|c|}{ Pop. Density } \\
\hline & $\begin{array}{c}\mathrm{HHC} \\
(1) \\
\end{array}$ & $\begin{array}{c}\mathrm{HH} \\
(2) \\
\end{array}$ & $\begin{array}{c}\text { HHCS } \\
(3)\end{array}$ & $\begin{array}{c}\text { HHS } \\
(4)\end{array}$ & $\begin{array}{c}\mathrm{HHC} \\
(5) \\
\end{array}$ & $\begin{array}{c}\mathrm{HH} \\
(6) \\
\end{array}$ & $\begin{array}{c}\mathrm{HHC} \\
(7) \\
\end{array}$ & $\begin{array}{c}\mathrm{HH} \\
(8) \\
\end{array}$ \\
\hline \multicolumn{9}{|c|}{$\begin{array}{l}\text { Panel A: First-Stage Regression } \\
\text { ndent Variable: Destination-to-Source Trust }\end{array}$} \\
\hline Somatic distance & $\begin{array}{c}-0.06^{* * * *} \\
(0.01)\end{array}$ & $\begin{array}{c}-0.09 * * * \\
(0.02)\end{array}$ & $\begin{array}{c}-0.06^{* * *} * \\
(0.01)\end{array}$ & $\begin{array}{c}-0.07 * * * \\
(0.01)\end{array}$ & $\begin{array}{c}-0.05^{* * *} \\
(0.01)\end{array}$ & $\begin{array}{c}-0.09 * * * \\
(0.02)\end{array}$ & $\begin{array}{c}-0.05^{* * *} * \\
(0.01)\end{array}$ & $\begin{array}{c}-0.08 * * * \\
(0.02)\end{array}$ \\
\hline Religious similarity & $\begin{array}{c}0.18 * * * \\
(0.06)\end{array}$ & $\begin{array}{c}0.15^{* *} \\
(0.06)\end{array}$ & $\begin{array}{c}0.20 * * * \\
(0.06)\end{array}$ & $\begin{array}{c}0.18 * * * \\
(0.06)\end{array}$ & $\begin{array}{c}0.17 * * * \\
(0.07)\end{array}$ & $\begin{array}{c}0.14^{* *} * \\
(0.06)\end{array}$ & $\begin{array}{c}0.15^{* *} \\
(0.06)\end{array}$ & $\begin{array}{c}0.15^{* *} \\
(0.06)\end{array}$ \\
\hline
\end{tabular}

Panel B: Reduced Form Equation of International trade

Dependent Variable: Aggregated Export Flows

$\begin{array}{lcccccccc}\text { Somatic distance } & -0.06^{*} & -0.06 & -0.02 & -0.01 & 0.01 & -0.04 & -0.03 & -0.06 \\ & (0.03) & (0.05) & (0.03) & (0.04) & (0.04) & (0.05) & (0.03) & (0.05) \\ \text { Religious similarity } & 0.11 & 0.09 & 0.12 & 0.11 & 0.12 & 0.09 & 0.10 & 0.09 \\ & (0.14) & (0.14) & (0.14) & (0.14) & (0.14) & (0.15) & (0.14) & (0.14)\end{array}$

Panel C: Second-Stage Estimates using somatic distance and religious similarity as instruments

Dependent Variable: Aggregated Export Flows

\begin{tabular}{|c|c|c|c|c|c|c|c|c|}
\hline DtS trust & $\begin{array}{r}0.85^{* *} \\
(0.35)\end{array}$ & $\begin{array}{l}0.69^{* *} \\
(0.34)\end{array}$ & $\begin{array}{c}0.46 \\
(0.31)\end{array}$ & $\begin{array}{c}0.35 \\
(0.35)\end{array}$ & $\begin{array}{c}0.20 \\
(0.36)\end{array}$ & $\begin{array}{c}0.55 \\
(0.36)\end{array}$ & $\begin{array}{c}0.55 \\
(0.37)\end{array}$ & $\begin{array}{l}0.69^{*} \\
(0.36)\end{array}$ \\
\hline Relevance & & & & & & & & \\
\hline $\begin{array}{l}\text { K-P } r k \text { LM Statistic } \\
\text { (p-value) }\end{array}$ & $\begin{array}{l}16.95 \\
(0.00)\end{array}$ & $\begin{array}{l}23.58 \\
(0.00)\end{array}$ & $\begin{array}{l}19.89 \\
(0.00)\end{array}$ & $\begin{array}{l}23.33 \\
(0.00)\end{array}$ & $\begin{array}{l}18.46 \\
(0.00)\end{array}$ & $\begin{array}{l}20.40 \\
(0.00)\end{array}$ & $\begin{array}{l}15.27 \\
(0.00)\end{array}$ & $\begin{array}{l}20.43 \\
(0.00)\end{array}$ \\
\hline $\begin{array}{l}\text { Weak Identification } \\
\text { K-P } r k \text { Wald Statistic }\end{array}$ & 16.93 & 21.27 & 19.95 & 21.30 & 13.48 & 21.58 & 15.74 & 20.80 \\
\hline $\begin{array}{l}\text { Exogeneity } \\
\text { Hansen } J \text {-Stat } \\
\text { (p-value) }\end{array}$ & $\begin{array}{c}0.13 \\
(0.72)\end{array}$ & $\begin{array}{c}0.02 \\
(0.90)\end{array}$ & $\begin{array}{c}0.06 \\
(0.80)\end{array}$ & $\begin{array}{c}0.21 \\
(0.65)\end{array}$ & $\begin{array}{c}0.58 \\
(0.45)\end{array}$ & $\begin{array}{c}0.01 \\
(0.91)\end{array}$ & $\begin{array}{c}0.01 \\
(0.91)\end{array}$ & $\begin{array}{c}0.02 \\
(0.90)\end{array}$ \\
\hline
\end{tabular}

Panel D: Second-Stage Estimates using Somatic Distance as Instrument

Dependent Variable: Aggregated Export Flows

\begin{tabular}{lcccccccc} 
DtS trust & $0.96^{* *}$ & 0.74 & 0.39 & 0.17 & -0.17 & 0.49 & 0.50 & 0.75 \\
& $(0.47)$ & $(0.51)$ & $(0.44)$ & $(0.52)$ & $(0.57)$ & $(0.59)$ & $(0.58)$ & $(0.58)$ \\
& & & & & & & & \\
Relevance & & & & & & & & \\
$\begin{array}{l}\text { K-P rk LM Statistic } \\
\text { (p-value) }\end{array}$ & 14.65 & 20.97 & 17.65 & 19.93 & 11.88 & 16.72 & 14.74 & 18.43 \\
Weak Identification & $(0.00)$ & $(0.00)$ & $(0.00)$ & $(0.00)$ & $(0.00)$ & $(0.00)$ & $(0.00)$ & $(0.00)$ \\
K-P rk Wald Statistic & 22.99 & 28.22 & 27.99 & 30.45 & 15.20 & 27.60 & 16.50 & 24.89 \\
R-squared & 0.68 & 0.70 & 0.72 & 0.72 & 0.72 & 0.71 & 0.71 & 0.70 \\
& 679 & 679 & 679 & 679 & 679 & 679 & 679 & 679 \\
\hline
\end{tabular}

Notes. This table presents the coefficients of estimating the first-stage regression (Panel A), the reduced form equation of the dependent variable (Panel B), the IV/GMM coefficients of estimating equation (1) when DtS trust is instrumented with both variables of cultural proximity of country-pairs (Panel C), and the IV estimates when instrumenting DtS trust only with a measure of somatic distance (Panel D). In each column, we use an alternative indicator of somatic distance as instrument for bilateral trust. In columns (1) to (4) we use the indicators made available by Guiso et al. (2008a), in columns (5) and (6) the indicators elaborated following the instructions given by them, and in columns (7) and (8) the measures that take the population density into account. The columns are labeled with the letters $H$, $C$, and $S: H$ stands for height and hair, $C$ for cephalic index, and $S$ for skin. The coefficients of the control variables (the same as in Table 2) are not reported. Cluster-robust standard errors are reported in parentheses and the coefficients are statistically different from zero at the $* * * 1 \%, * * 5 \%$, and $* 10 \%$ level. 
first, trying to replicate the measure actually used in GSZ following their instructions (column (5) $)^{26}$ and, second, disregarding the potentially problematic cephalic index. Finally, the ones used for the last two columns take the distribution of the population within a country into account, first, by accounting for the cephalic index (column (7)), and, second, by disregarding it (column (8)). ${ }^{27}$

According to Panel A of Table 3, the first-stage OLS coefficients on the instrumental variables are significantly different from zero in every column and the point-estimates are similar across the various indicators within a row. Panel C and D present the statistics that give indications on the validity of the instruments. According to these statistics, all the instruments are equally relevant, exogenous, and strong. Therefore, one may expect to find similar results in the reduced form and in the second stage, no matter which IV strategy we choose to apply. However, this is not what we observe. When estimating the reduced-form equation (2), according to Panel B, we find a significant coefficient on somatic distance only in column (1) where we employ the original indicator of GSZ. Consequently, the only IV coefficients on DtS trust that are significant in Panel $\mathrm{C}$ and in Panel D are the ones instrumented with the somatic distance measure employed by GSZ. As soon as we use an alternative measure of somatic distance as instrument (columns (2)-(8)), the significance of the trust coefficients disappears and the magnitude decreases and even becomes negative.

The fact that DtS trust does not remain significant in the trade regression when we instrument it with alternative measures of somatic distance that are equally valid suggests that there is no causal relationship between bilateral trust and international trade. The significant coefficient on DtS trust found in GSZ and in column (1) of Table 3 might result from a statistical type 1 error, i.e. the null hypothesis $\beta_{1}=0$ is rejected although it applies.

In the next section, we use a similar framework to analyze the causal relationship between bilateral trust and international migration. Applying the same sensitivity analysis, we investigate the effects of both DtS and StD trust.

\footnotetext{
${ }^{26}$ For several country-pairs, we did not manage to do so which may explain the diverging results.

${ }^{27}$ Recall the discussion in section 2.2 .
} 


\section{Bilateral Trust and International Migration}

As exposed earlier, we have reasons to suspect bilateral trust to affect international migration. StD trust might influence the way expectations on costs and benefits of moving abroad are shaped while DtS trust may, for example, affect immigration policies in the destination countries. These two measures of bilateral trust are highly correlated. Therefore, in order to separately estimate the effect that StD trust and DtS trust have on international migration, we need to define two specifications:

$$
\begin{aligned}
& \log \left(m i g_{s d, t}\right)=\alpha_{0}+\alpha_{1} \text { trust }_{s d, t}+\alpha_{2} \Delta G D P_{s d, t}+\mathbf{X}_{s d}^{\prime} \gamma+\lambda_{s, t}+\lambda_{d, t}+\epsilon_{s d, t}, \\
& \log \left(m i g_{s d, t}\right)=\beta_{0}+\beta_{1} \text { trust }_{d s, t}+\beta_{2} \Delta G D P_{s d, t}+\mathbf{X}_{s d}^{\prime} \rho+\lambda_{s, t}+\lambda_{d, t}+e_{s d, t},
\end{aligned}
$$

where the dependent variable, denoted by $\log \left(m i g_{s d, t}\right)$, is the natural logarithm of the (gross) immigration flows from country-of-origin $s$ to country-of-destination $d$ in period t. trust $_{s d, t}$ and trust $_{d s, t}$ stand for the StD and DtS trust observed in year $t$, respectively. $\triangle G D P_{s d, t}$ measures the percentage difference in the gross domestic product (GDP) per capita of two countries. We use this variable as a proxy for the wage differential between a country-pair. $\mathbf{X}_{s d}^{\prime}$ is a vector of bilateral time-invariant variables, $\lambda_{s, t}$ and $\lambda_{d, t}$ are country-year fixed effects, and $\epsilon_{s d, t}$ and $e_{s d, t}$ are mean-zero random variables accounting for random shocks.

To estimate these specifications, we use data on immigration flows collected by Ortega and Peri $(2009,2011)$. They merged and harmonized data sets gathered by Mayda (2010), the United Nations, and the OECD (International Migration Database, IMD) to establish an unbalanced panel of annual data on bilateral gross immigration flows into 30 OECD countries from 1946 to 2008. This unique dataset details the legal entry of foreign citizens who wish to be residents in an OECD country. Consistency is ensured by verifying that immigrants are always defined on the same basis across the database for each destination country. To complete the dataset, Ortega and Peri (2009, 2011) interpolate observations in a limited number of cases $^{28}$ and compute the

\footnotetext{
${ }^{28}$ They interpolate observations only when the missing value is situated between two years for which
} 
net immigration flows. They correct for the outflow of foreign citizens using the IMD and the dataset on emigration stocks for the years 1990 and 2000 collected by Docquier, Lowell and Marfouk (2007), who count as migrant all foreign-born individuals aged 25+ that live in a OECD country and class the emigrants by educational attainment and gender. ${ }^{29}$ However, these net immigration flows are less precise than the gross flows and only have a limited coverage. We therefore focus on the analysis of the impact of bilateral trust on gross inflows of foreign nationals. The other variables are identical to the ones used in the trade setting.

Panel B of Table 1 reports the summary statistics of the sample used to analyze the relationship between international migration and StD trust, and Panel C to regress international migration on DtS trust. The number of observations varies across panels because of missing data. We again focus on observations for European countries in the years for which we have data on bilateral trust.

The results from estimating equations (4) and (5) are reported in Panel A and Panel B of Table 4, respectively. The first three columns present standard OLS estimates. They suggest that a one percent increase in the difference in GDP per capita increases immigration flows on average by approximately two percent. This positive and significant effect is in line with the notion, typically supported by the data, that international wage differentials affect migration patterns. We also find that geographical distance between countries has a significant and negative effect on the dependent variable. ${ }^{30}$ Sharing the legal origin has a positive effect.

The main finding from columns (1)-(3) is the absence of a significant correlation between bilateral trust and immigration flows. In Column (1) of Panel A, the coefficient on StD trust is positive but rather small and not significantly different from zero. In Column (2), we include an indicator of the existing diaspora in the destination countries. Beine et al. (2011) showed that an increase in the past stock of migrants

\footnotetext{
the observations are available.

${ }^{29}$ The dataset can be downloaded from Frédéric Docquier's Homepage under http://perso.uclouvain.be/frederic.docquier/oxlight.htm

${ }^{30}$ In this section, we always include the measure of weighted distance provided by Mayer and Zignago (2011).
} 
Table 4

Determinants of Migration

\begin{tabular}{|c|c|c|c|c|c|c|}
\hline & $\begin{array}{c}\text { OLS } \\
(1) \\
\end{array}$ & $\begin{array}{c}\text { OLS } \\
(2) \\
\end{array}$ & $\begin{array}{c}\text { OLS } \\
(3) \\
\end{array}$ & $\begin{array}{c}\text { IV-SR } \\
(4) \\
\end{array}$ & $\begin{array}{c}\text { IV-S } \\
(5) \\
\end{array}$ & $\begin{array}{l}\mathrm{RF} \\
(6) \\
\end{array}$ \\
\hline \multicolumn{7}{|c|}{ Panel A Source-to-Destination Trust } \\
\hline Trust (StD) & $\begin{array}{c}0.68 \\
(0.59)\end{array}$ & $\begin{array}{c}0.43 \\
(0.60)\end{array}$ & $\begin{array}{c}0.23 \\
(0.65)\end{array}$ & $\begin{array}{c}2.22 * * \\
(0.93)\end{array}$ & $\begin{array}{c}2.40 \\
(1.51)\end{array}$ & \\
\hline Diff. in GDP p.c. (\%) & $\begin{array}{l}1.66^{*} \\
(0.86)\end{array}$ & $\begin{array}{c}2.07 * * \\
(0.87)\end{array}$ & $\begin{array}{l}1.93 * * \\
(0.84)\end{array}$ & $\begin{array}{c}2.50 * * \\
(0.96)\end{array}$ & $\begin{array}{c}2.55^{* *} \\
(1.02)\end{array}$ & $\begin{array}{c}2.01 * * \\
(0.84)\end{array}$ \\
\hline Common language & $\begin{array}{l}-0.24 \\
(0.34)\end{array}$ & $\begin{array}{l}-0.36 \\
(0.33)\end{array}$ & $\begin{array}{l}-0.27 \\
(0.33)\end{array}$ & $\begin{array}{l}-0.41 \\
(0.28)\end{array}$ & $\begin{array}{l}-0.42 \\
(0.29)\end{array}$ & $\begin{array}{l}-0.25 \\
(0.35)\end{array}$ \\
\hline Weighted Distance (log) & $\begin{array}{c}-0.70 * * \\
(0.31)\end{array}$ & $\begin{array}{l}-0.57 * \\
(0.30)\end{array}$ & $\begin{array}{c}-0.55^{*} \\
(0.30)\end{array}$ & $\begin{array}{l}-0.41 \\
(0.27)\end{array}$ & $\begin{array}{l}-0.41 \\
(0.29)\end{array}$ & $\begin{array}{l}-0.47 \\
(0.30)\end{array}$ \\
\hline Common border & $\begin{array}{c}0.00 \\
(0.34)\end{array}$ & $\begin{array}{c}0.26 \\
(0.38)\end{array}$ & $\begin{array}{c}0.21 \\
(0.38)\end{array}$ & $\begin{array}{c}0.30 \\
(0.30)\end{array}$ & $\begin{array}{c}0.30 \\
(0.29)\end{array}$ & $\begin{array}{c}0.23 \\
(0.37)\end{array}$ \\
\hline Same legal origin & $\begin{array}{c}0.61 * * * \\
(0.24)\end{array}$ & $\begin{array}{c}0.69 * * * \\
(0.23)\end{array}$ & $\begin{array}{l}0.52 * \\
(0.27)\end{array}$ & $\begin{array}{c}0.54 * * * \\
(0.20)\end{array}$ & $\begin{array}{c}0.56^{* *} \\
(0.22)\end{array}$ & $\begin{array}{c}0.53 * * \\
(0.26)\end{array}$ \\
\hline Mig. Stock $1960(\log )$ & & $\begin{array}{l}0.33^{*} \\
(0.18)\end{array}$ & $\begin{array}{l}0.30^{*} \\
(0.17)\end{array}$ & $\begin{array}{c}0.24 \\
(0.15)\end{array}$ & $\begin{array}{c}0.23 \\
(0.16)\end{array}$ & $\begin{array}{l}0.32 * \\
(0.17)\end{array}$ \\
\hline Religious similarity & & & $\begin{array}{c}0.50 \\
(0.46)\end{array}$ & & $\begin{array}{l}-0.08 \\
(0.56)\end{array}$ & $\begin{array}{c}0.43 \\
(0.39)\end{array}$ \\
\hline Somatic Distance used in GSZ & & & & & & $\begin{array}{l}-0.09 \\
(0.07)\end{array}$ \\
\hline $\begin{array}{l}\text { Relevance } \\
\text { K-P rk LM Statistic } \\
\text { (p-value) }\end{array}$ & & & & $\begin{array}{l}21.61 \\
(0.00)\end{array}$ & $\begin{array}{l}13.99 \\
(0.00)\end{array}$ & \\
\hline $\begin{array}{l}\text { Weak Identification } \\
\text { K-P rk Wald Statistic }\end{array}$ & & & & 14.41 & 12.37 & \\
\hline $\begin{array}{l}\text { Over-identification } \\
\text { Hansen } J \text {-Stat } \\
\text { (p-value) }\end{array}$ & & & & $\begin{array}{c}0.02 \\
(0.88) \\
\end{array}$ & & \\
\hline
\end{tabular}

Panel B Destination-to-Source Trust

\begin{tabular}{|c|c|c|c|c|c|c|}
\hline Trust (DtS) & $\begin{array}{c}0.62 \\
(0.57)\end{array}$ & $\begin{array}{c}0.33 \\
(0.60)\end{array}$ & $\begin{array}{c}0.22 \\
(0.62)\end{array}$ & $\begin{array}{l}1.78 * \\
(0.99)\end{array}$ & $\begin{array}{c}1.53 \\
(1.02)\end{array}$ & \\
\hline Diff. in GDP p.c. (\%) & $\begin{array}{l}1.64 * \\
(0.84)\end{array}$ & $\begin{array}{c}2.05^{* *} \\
(0.84)\end{array}$ & $\begin{array}{c}1.97 * * \\
(0.82)\end{array}$ & $\begin{array}{c}2.01 * * \\
(0.78)\end{array}$ & $\begin{array}{c}2.05 * * * \\
(0.76)\end{array}$ & $\begin{array}{c}2.10^{* * *} \\
(0.81)\end{array}$ \\
\hline Common language & $\begin{array}{l}-0.15 \\
(0.35)\end{array}$ & $\begin{array}{l}-0.30 \\
(0.34)\end{array}$ & $\begin{array}{l}-0.22 \\
(0.34)\end{array}$ & $\begin{array}{l}-0.18 \\
(0.29)\end{array}$ & $\begin{array}{l}-0.19 \\
(0.29)\end{array}$ & $\begin{array}{l}-0.22 \\
(0.36)\end{array}$ \\
\hline Weighted Distance (log) & $\begin{array}{c}-0.73 * * \\
(0.31)\end{array}$ & $\begin{array}{c}-0.61 * * \\
(0.30)\end{array}$ & $\begin{array}{l}-0.58^{*} \\
(0.29)\end{array}$ & $\begin{array}{l}-0.51 * \\
(0.27)\end{array}$ & $\begin{array}{c}-0.52 * * \\
(0.26)\end{array}$ & $\begin{array}{l}-0.50 \\
(0.31)\end{array}$ \\
\hline Common border & $\begin{array}{l}-0.04 \\
(0.33)\end{array}$ & $\begin{array}{c}0.23 \\
(0.39)\end{array}$ & $\begin{array}{c}0.19 \\
(0.39)\end{array}$ & $\begin{array}{c}0.15 \\
(0.28)\end{array}$ & $\begin{array}{c}0.14 \\
(0.29)\end{array}$ & $\begin{array}{c}0.22 \\
(0.37)\end{array}$ \\
\hline Same legal origin & $\begin{array}{c}0.57 * * \\
(0.25)\end{array}$ & $\begin{array}{c}0.65 * * * \\
(0.23)\end{array}$ & $\begin{array}{l}0.49 * \\
(0.27)\end{array}$ & $\begin{array}{c}0.51 * * \\
(0.21)\end{array}$ & $\begin{array}{c}0.47^{* *} \\
(0.22)\end{array}$ & $\begin{array}{l}0.51^{*} \\
(0.26)\end{array}$ \\
\hline Mig. Stock $1960(\log )$ & & $\begin{array}{l}0.31 * \\
(0.17)\end{array}$ & $\begin{array}{c}0.28 \\
(0.18)\end{array}$ & $\begin{array}{c}0.18 \\
(0.16)\end{array}$ & $\begin{array}{c}0.20 \\
(0.16)\end{array}$ & $\begin{array}{l}0.30^{*} \\
(0.17)\end{array}$ \\
\hline Religious similarity & & & $\begin{array}{c}0.46 \\
(0.39)\end{array}$ & & $\begin{array}{c}0.25 \\
(0.33)\end{array}$ & $\begin{array}{c}0.36 \\
(0.39)\end{array}$ \\
\hline Somatic Distance used in GSZ & & & & & & $\begin{array}{l}-0.08 \\
(0.06)\end{array}$ \\
\hline $\begin{array}{l}\text { Relevance } \\
\text { K-P rk LM Statistic } \\
\text { (p-value) }\end{array}$ & & & & $\begin{array}{l}13.93 \\
(0.00)\end{array}$ & $\begin{array}{l}11.09 \\
(0.00)\end{array}$ & \\
\hline $\begin{array}{l}\text { Weak Identification } \\
\text { K-P rk Wald Statistic }\end{array}$ & & & & 15.05 & 20.49 & \\
\hline $\begin{array}{l}\text { Over-identification } \\
\text { Hansen } J \text {-Stat } \\
\text { (p-value) }\end{array}$ & & & & $\begin{array}{c}0.60 \\
(0.44)\end{array}$ & & \\
\hline $\begin{array}{l}\text { Observations } \\
\text { R-squared }\end{array}$ & $\begin{array}{l}463 \\
0.89\end{array}$ & $\begin{array}{l}463 \\
0.89\end{array}$ & $\begin{array}{l}463 \\
0.89\end{array}$ & 463 & 463 & $\begin{array}{l}463 \\
0.90\end{array}$ \\
\hline
\end{tabular}

Notes. The dependent variable is the natural logarithm of the migration flows from country $s$ to country $d$ (Ortega and Peri, 2009, 2011). Trust (StD) measures the average trust that citizens in country $s$ grant citizens in country $d$, and Trust (DtS) is the reciprocal trust (Eurobarometer Surveys). Somatic distance is the measure used in GSZ which sums the absolute value on the difference in the hair color, height, and cephalic index. All equations include countryyear dummies. Robust standard errors are reported in parentheses, which are clustered at the country-pair. Coefficients are statistically different from zero at the ***1\%,**5\%, and *10\% level. Columns (1) - (3) present OLS estimates; columns (4) and (5) present IV estimates with somatic distance and religious similarity as instruments (IV-SR) and with somatic distance as only instrument (IV-S), respectively. RF (column (6)) refers to the reduced form equation of the dependent variables (see appendix). 
in a country raises migration flows, possibly because a larger diaspora reduces costs and risks migrants face when moving abroad. We capture such network effects by a proxy for the emigration stocks in 1960 as employed in Grossmann and Stadelmann (2012). This variable ensures a lag of at least 10 years that exists between the proxy and the observations included in our regression. It is itself significant and positive, as found in previous studies. Adding it decreases the coefficient of StD trust which is still statistically insignificant. We observe the same pattern when including religious similarity as control variable in column (3): it halves the coefficient of StD trust and slightly increases its standard error. The OLS estimates hence suggest that StD trust is not significantly related to international migration.

We next, again, apply the IV estimation proposed in GSZ and perform a sensitivity analysis to examine whether the IV strategies follow a similar pattern in the migration setting as they followed in the trade setting. Using the somatic distance measure as employed in GSZ and religious similarity as instruments, the coefficient on StD trust strongly increases compared to the OLS estimates and becomes significantly different from zero at the five percent level (column (4)). The employed instruments pass the Hansen $J$-test. The Kleinbergen-Paap $r k$ statistics suggest that they are relevant and strong. Nevertheless, like for Table 2, there are several reasons to regard the results in column (4) with caution. First, the IV estimate on StD trust is five times larger than the OLS counterpart. It suggests that an increase in StD trust of one standard deviation increases gross immigration flows on average by 66 percent, which is a surprisingly large effect in view of the OLS estimate. Second, religious similarity may affect international migration not exclusively through the trust channel. Finally, the previous section suggests that the coefficient on bilateral trust might not be robust to the use of alternative measures of somatic distance as instruments.

To address these concerns, we first estimate an alternative specification which includes the proxy for religious similarity as explanatory variable. Column (5) reports the results when we employ the indicator of somatic distance used in GSZ as sole instrumental variable. The IV coefficient on StD trust is similar in magnitude but it 
loses its significance. Column (6) reports the results from estimating a reduced-form equation analogously to (3). It suggests that neither somatic distance nor religious similarity are correlated with international migration in the reduced form. This absence of correlation between the instrumental variables and the dependent variable as well as the insignificant coefficients found in columns (1)-(3) raise doubts on the finding in column (4) that StD trust affects a migrant's decision to move abroad.

In Panel B of Table 4, the relationship between DtS trust and international migration is similar to the one observed in Panel A between StD trust and international migration. In columns (1)-(3), the OLS estimates of the coefficient of DtS trust are positive but not statistically significant. Instrumenting DtS trust with indicators of religious similarity and somatic distance in column (4) yields significant results, here at the ten percent level, that are more than five times larger than their OLS counterparts. They suggest that an increase of DtS trust of one standard deviation increases immigration flows on average by 56 percent. However, according to column (5), when including religious similarity as a covariate of migration rather than as an instrument for trust, the coefficient on DtS trust becomes insignificant. Moreover, also similar to Panel A, column (6) shows that the correlation between the instruments and international migration is again insignificant in the reduced-form equation.

In view of these inconclusive results with respect to the relationship between bilateral trust and international migration, we again exploit the fact that there is a large degree of freedom in the definition of somatic distance and estimate regressions (4) and (5) with the same covariates and the same sample again, only changing the somatic distance indicator which we use as instrument. The results of this analysis are reported in Table 5 for the relationship between international migration and StD trust, and in Table 6 for its relationship with DtS trust.

In columns (1) of Panels B, C and D of Table 5 we restate the most important results of Panel A in Table 4 (columns (6), (4) and (5), respectively). Panel A of Table 5 additionally reports the first-stage coefficients on somatic distance and religious similarity when we regress StD trust on all included and excluded exogenous variables. 
Table 5

Migration Regression: Instrumenting StD Trust with Alternative Measures of Somatic Distance

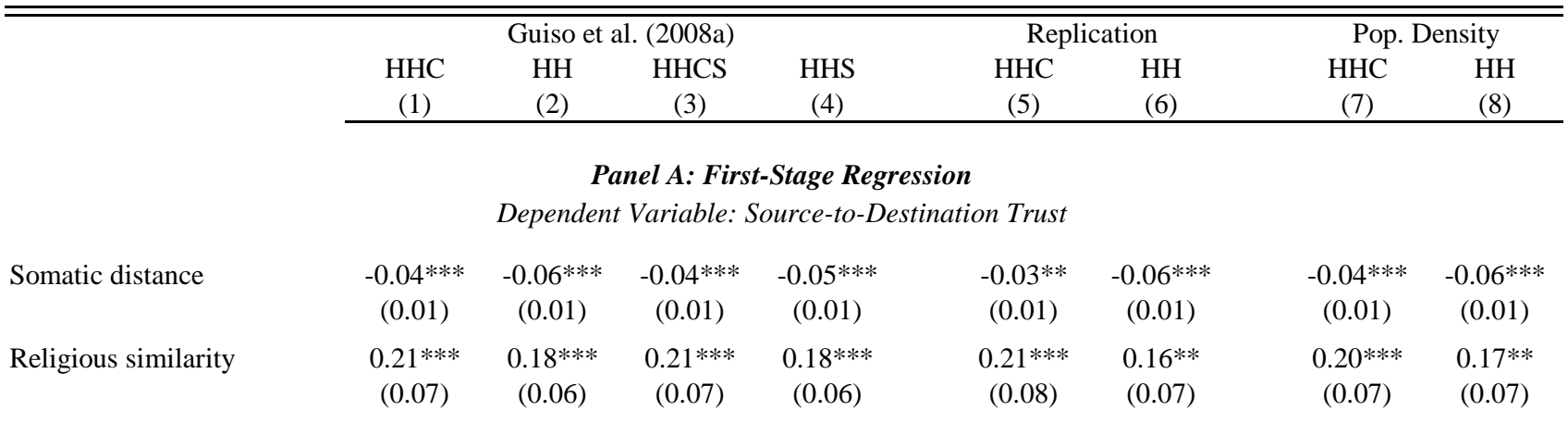

Panel B: Reduced Form Equation of International Migration

Dependent Variable: International Immigration Flows

$\begin{array}{lcccccccc}\text { Somatic distance } & -0.09 & -0.09 & 0.01 & 0.03 & 0.01 & -0.02 & -0.08 & -0.07 \\ & (0.07) & (0.08) & (0.06) & (0.08) & (0.07) & (0.10) & (0.07) & (0.09) \\ \text { Religious similarity } & 0.43 & 0.41 & 0.58 & 0.60 & 0.58 & 0.53 & 0.42 & 0.44 \\ & (0.39) & (0.40) & (0.43) & (0.45) & (0.45) & (0.46) & (0.40) & (0.41)\end{array}$

Panel C: Second-Stage Estimates using somatic distance and religious similarity as instruments Dependent Variable: International Immigration Flows

\begin{tabular}{|c|c|c|c|c|c|c|c|}
\hline StD trust & $\begin{array}{l}2.22 * * \\
(0.93)\end{array}$ & $\begin{array}{l}1.84 * * \\
(0.80)\end{array}$ & $\begin{array}{c}0.95 \\
(0.83)\end{array}$ & $\begin{array}{c}0.83 \\
(0.79)\end{array}$ & $\begin{array}{c}1.27 \\
(0.85)\end{array}$ & $\begin{array}{l}1.25 \\
(0.81)\end{array}$ & $\begin{array}{l}2.00^{* * *} \\
(0.89)\end{array}$ \\
\hline Relevance & & & & & & & \\
\hline $\begin{array}{l}\text { K-P } r k \text { LM Statistic } \\
\text { (p-value) }\end{array}$ & $\begin{array}{l}21.61 \\
(0.00)\end{array}$ & $\begin{array}{l}25.88 \\
(0.00)\end{array}$ & $\begin{array}{l}24.39 \\
(0.00)\end{array}$ & $\begin{array}{l}26.94 \\
(0.00)\end{array}$ & $\begin{array}{l}21.68 \\
(0.00)\end{array}$ & $\begin{array}{l}24.99 \\
(0.00)\end{array}$ & $\begin{array}{l}20.80 \\
(0.00)\end{array}$ \\
\hline $\begin{array}{l}\text { Weak Identification } \\
\text { K-P } r k \text { Wald Statistic }\end{array}$ & 14.41 & 16.10 & 18.64 & 19.19 & 12.54 & 17.59 & 14.74 \\
\hline $\begin{array}{l}\text { Exogeneity } \\
\text { Hansen } J \text {-Stat } \\
\text { (p-value) }\end{array}$ & $\begin{array}{c}0.02 \\
(0.88)\end{array}$ & $\begin{array}{c}0.07 \\
(0.80)\end{array}$ & $\begin{array}{c}1.79 \\
(0.18)\end{array}$ & $\begin{array}{c}2.12 \\
(0.15)\end{array}$ & $\begin{array}{c}0.90 \\
(0.34)\end{array}$ & $\begin{array}{c}0.90 \\
(0.34)\end{array}$ & $\begin{array}{c}0.01 \\
(0.93)\end{array}$ \\
\hline
\end{tabular}

Panel D: Second-Stage Estimates using Somatic Distance as Instrument Dependent Variable: International Immigration Flows

\begin{tabular}{|c|c|c|c|c|c|c|c|c|}
\hline StD trust & $\begin{array}{c}2.40 \\
(1.51)\end{array}$ & $\begin{array}{c}1.60 \\
(1.23)\end{array}$ & $\begin{array}{l}-0.33 \\
(1.30)\end{array}$ & $\begin{array}{l}-0.47 \\
(1.23)\end{array}$ & $\begin{array}{c}-0.36 \\
(1.79)\end{array}$ & $\begin{array}{c}0.24 \\
(1.36)\end{array}$ & $\begin{array}{c}1.89 \\
(1.50)\end{array}$ & $\begin{array}{c}1.28 \\
(1.33\end{array}$ \\
\hline $\begin{array}{l}\text { Relevance } \\
\text { K-P rk LM Statistic } \\
\text { (p-value) }\end{array}$ & $\begin{array}{l}13.99 \\
(0.00)\end{array}$ & $\begin{array}{l}22.52 \\
(0.00)\end{array}$ & $\begin{array}{l}20.47 \\
(0.00)\end{array}$ & $\begin{array}{l}23.71 \\
(0.00)\end{array}$ & $\begin{array}{c}8.23 \\
(0.00)\end{array}$ & $\begin{array}{l}17.72 \\
(0.00)\end{array}$ & $\begin{array}{l}17.50 \\
(0.00)\end{array}$ & $\begin{array}{l}19.50 \\
(0.00)\end{array}$ \\
\hline $\begin{array}{l}\text { Weak Identification } \\
\text { K-P rk Wald Statistic }\end{array}$ & 12.37 & 18.11 & 19.65 & 23.80 & 5.54 & 18.62 & 12.85 & 19.30 \\
\hline Observations & 450 & 450 & 450 & 450 & 450 & 450 & 450 & 450 \\
\hline
\end{tabular}

Notes. This table presents the coefficients of estimating the first-stage regression (Panel A), the reduced form equation of the dependent variable (Panel B), the IV/GMM coefficients of estimating equation (3) when StD trust is instrumented with both variables of cultural proximity of country-pairs (Panel C), and the IV estimates when instrumenting StD trust only with a measure of somatic distance (Panel D). In each column, we use an alternative indicator of somatic distance as instrument for bilateral trust. In columns (1) to (4) we use the indicators made available by GSZ, in columns (5) and (6) the indicators elaborated following the instructions given by Guiso et al. (2008a), and in columns (7) and (8) the measures that take the population density into account. The columns are labeled with the letters $H, C$, and $S: H$ stands for height and hair, $C$ for cephalic index, and $S$ for skin. The coefficients of the control variables (the same as in Table 2) are not reported. Cluster-robust standard errors are reported in parentheses and the coefficients are statistically different from zero at the $* * * 1 \%, * * 5 \%$, and $* 10 \%$ level. 
As in the case where international trade flows are the dependent variable at the second stage, we observe that the various measures of somatic distance are equally significant at the first stage and that the coefficients are similar across the different columns. However, that none of these indicators are correlated with international migration in the reduced-form equation (Panel B) suggests that StD trust does not have a causal impact on international migration.

Panel C reports second-stage results for the case where the eight measures of somatic distance are used as instruments jointly with religious similarity. Whereas second-stage estimates for the coefficients on StD trust are significant in columns (1), (2), (7) and (8), they are insignificant in the other columns. Given the questionable validity of religious similarity as instrumental variable for bilateral trust, in Panel D, we report the trust coefficients when instrumenting StD trust solely with the measures of somatic distance (again including religious similarity as a control variable). Consistent with the results found in panel B, none of the estimations yield statistically significant coefficients and some even have a negative sign. Interestingly, the point estimate is again highest and economically (though not statistically) most significant when using the somatic distance measure originally used by GSZ as an instrument for StD trust.

Regarding the effect of DtS trust on migration, Table 6 provides a sensitivity analysis of the results in Panel B of Table 4. Column (1) of Panels B, C and D of Table 6 restate the most important results. According to Panel A of Table 6, all indicators of somatic distance significantly affect DtS trust at the five percent level. However, again, none of them are correlated with international migration in the reduced-form equation (Panel B). Panel C reports the IV estimates when using somatic distance and religious similarity as instruments for DtS trust. Analogously to the results found in Panel C of Table 5, we see that the tests suggest that the instruments are relevant and exogenous. Moreover, the coefficients on instrumented DtS trust are sometimes significant at the second stage. However, according to Panel A, the indicator of religious similarity is not correlated with DtS trust and, as repeatedly mentioned, a potentially problematic instrument. Panel D of Table 6 shows the second-stage estimates when instrumenting 
Table 6

Migration Regression: Instrumenting DtS Trust with Alternative Measures of Somatic Distance

\begin{tabular}{|c|c|c|c|c|c|c|c|c|}
\hline & \multicolumn{4}{|c|}{ Guiso et al. (2009) } & \multicolumn{2}{|c|}{ Replication } & \multicolumn{2}{|c|}{ Pop. Density } \\
\hline & $\begin{array}{c}\mathrm{HHC} \\
(1)\end{array}$ & $\begin{array}{c}\mathrm{HH} \\
(2)\end{array}$ & $\begin{array}{c}\text { HHCS } \\
(3)\end{array}$ & $\begin{array}{c}\text { HHS } \\
(4)\end{array}$ & $\begin{array}{l}\mathrm{HHC} \\
(5)\end{array}$ & $\begin{array}{c}\mathrm{HH} \\
(6)\end{array}$ & $\begin{array}{c}\mathrm{HHC} \\
(7)\end{array}$ & $\begin{array}{c}\mathrm{HH} \\
(8)\end{array}$ \\
\hline \multicolumn{9}{|c|}{$\begin{array}{c}\text { Panel A: First-Stage Regression } \\
\text { Dependent Variable: Destination-to-Source Trust }\end{array}$} \\
\hline Somatic distance & $\begin{array}{c}-0.06 * * * \\
(0.01)\end{array}$ & $\begin{array}{c}-0.06 * * * \\
(0.01)\end{array}$ & $\begin{array}{c}-0.05 * * * \\
(0.01)\end{array}$ & $\begin{array}{c}-0.05^{* * *} \\
(0.01)\end{array}$ & $\begin{array}{c}-0.05 * * * \\
(0.01)\end{array}$ & $\begin{array}{c}-0.06 * * * \\
(0.02)\end{array}$ & $\begin{array}{c}-0.06^{* * * *} \\
(0.01)\end{array}$ & $\begin{array}{c}-0.05^{* * *} \\
(0.01)\end{array}$ \\
\hline Religious similarity & $\begin{array}{c}0.07 \\
(0.07)\end{array}$ & $\begin{array}{c}0.06 \\
(0.07)\end{array}$ & $\begin{array}{c}0.08 \\
(0.07)\end{array}$ & $\begin{array}{c}0.07 \\
(0.07)\end{array}$ & $\begin{array}{c}0.08 \\
(0.08)\end{array}$ & $\begin{array}{c}0.06 \\
(0.08)\end{array}$ & $\begin{array}{c}0.06 \\
(0.07)\end{array}$ & $\begin{array}{c}0.06 \\
(0.07)\end{array}$ \\
\hline
\end{tabular}

Panel B: Reduced Form Equation of International Migration

Dependent Variable: International Immigration Flows

$\begin{array}{lcccccccc}\text { Somatic distance } & -0.08 & -0.08 & 0.02 & 0.03 & 0.01 & -0.00 & -0.08 & -0.06 \\ & (0.06) & (0.08) & (0.06) & (0.08) & (0.07) & (0.10) & (0.07) & (0.08) \\ \text { Religious similarity } & 0.36 & 0.36 & 0.52 & 0.55 & 0.51 & 0.49 & 0.35 & 0.39 \\ & (0.39) & (0.40) & (0.42) & (0.44) & (0.45) & (0.46) & (0.39) & (0.41)\end{array}$

Panel C: Second-Stage Estimates using somatic distance and religious similarity as instruments

Dependent Variable: International Immigration Flows

\begin{tabular}{|c|c|c|c|c|c|c|c|c|}
\hline DtS trust & $\begin{array}{l}1.78^{*} \\
(0.99)\end{array}$ & $\begin{array}{l}1.77 * \\
(1.06)\end{array}$ & $\begin{array}{c}0.29 \\
(0.89)\end{array}$ & $\begin{array}{c}0.39 \\
(1.02)\end{array}$ & $\begin{array}{c}0.77 \\
(0.98)\end{array}$ & $\begin{array}{l}1.13 \\
(1.19)\end{array}$ & $\begin{array}{l}1.64 * \\
(1.00)\end{array}$ & $\begin{array}{c}1.63 \\
(1.17)\end{array}$ \\
\hline Relevance & & & & & & & & \\
\hline $\begin{array}{l}\text { K-P rk LM Statistic } \\
\text { (p-value) }\end{array}$ & $\begin{array}{l}13.93 \\
(0.00)\end{array}$ & $\begin{array}{l}15.21 \\
(0.00)\end{array}$ & $\begin{array}{l}13.88 \\
(0.00)\end{array}$ & $\begin{array}{l}14.52 \\
(0.00)\end{array}$ & $\begin{array}{l}13.15 \\
(0.00)\end{array}$ & $\begin{array}{l}11.70 \\
(0.00)\end{array}$ & $\begin{array}{l}15.97 \\
(0.00)\end{array}$ & $\begin{array}{l}13.97 \\
(0.00)\end{array}$ \\
\hline $\begin{array}{l}\text { Weak Identification } \\
\text { K-P } r k \text { Wald Statistic }\end{array}$ & 15.05 & 11.37 & 14.19 & 10.10 & 13.23 & 8.62 & 14.73 & 10.10 \\
\hline $\begin{array}{l}\text { Exogeneity } \\
\text { Hansen } J \text {-Stat } \\
\text { (p-value) }\end{array}$ & $\begin{array}{c}0.60 \\
(0.44)\end{array}$ & $\begin{array}{c}0.65 \\
(0.42)\end{array}$ & $\begin{array}{c}2.50 \\
(0.11)\end{array}$ & $\begin{array}{c}2.48 \\
(0.12)\end{array}$ & $\begin{array}{c}1.88 \\
(0.17)\end{array}$ & $\begin{array}{c}1.59 \\
(0.21)\end{array}$ & $\begin{array}{c}0.74 \\
(0.39)\end{array}$ & $\begin{array}{c}0.88 \\
(0.35)\end{array}$ \\
\hline
\end{tabular}

Panel D: Second-Stage Estimates using Somatic Distance as Instrument Dependent Variable: International Immigration Flows

\begin{tabular}{lcccccccc} 
DtS trust & 1.53 & 1.39 & -0.37 & -0.65 & -0.29 & 0.05 & 1.40 & 1.06 \\
& $(1.02)$ & $(1.16)$ & $(1.03)$ & $(1.29)$ & $(1.29)$ & $(1.52)$ & $(1.05)$ & $(1.33)$ \\
& & & & & & & & \\
Relevance & & & & & & & 12.79 & 10.71 \\
$\begin{array}{l}\text { K-P } \text { rk LM Statistic } \\
\text { (p-value) }\end{array}$ & 11.09 & 13.19 & 11.82 & 13.10 & 7.83 & 8.44 & $(0.00)$ & $(0.00)$ \\
Weak Identification & $(0.00)$ & $(0.00)$ & $(0.00)$ & $(0.00)$ & $(0.01)$ & $(0.00)$ & & \\
K-P rk Wald Statistic & & & & & & & & \\
Observations & 20.49 & 17.22 & 22.35 & 16.22 & 14.61 & 10.73 & 46.49 & 14.29 \\
\hline \hline
\end{tabular}

Notes. This table presents the coefficients of estimating the first-stage regression (Panel A), the reduced form equation of the dependent variable (Panel B), the IV/GMM coefficients of estimating equation (4) when DtS trust is instrumented with both variables of cultural proximity of country-pairs (Panel C), and the IV estimates when instrumenting DtS trust only with a measure of somatic distance (Panel D). In each column, we use an alternative indicator of somatic distance as instrument for bilateral trust. In columns (1) to (4) we use the indicators made available by GSZ, in columns (5) and (6) the indicators elaborated following the instructions given by Guiso et al. (2008a), and in columns (7) and (8) the measures that take the population density into account. The columns are labeled with the letters $H, C$, and $S: H$ stands for height and hair, $C$ for cephalic index, and $S$ for skin. The coefficients of the control variables (the same as in Table 2) are not reported. Cluster-robust standard errors are reported in parentheses and the coefficients are statistically different from zero at the $* * * 1 \%, * * 5 \%$, and $* 10 \%$ level. 
DtS trust with the various measures of somatic distance as sole instruments. Consistent with the reduced-form results in Panel B, the coefficients on instrumented DtS trust are all statistically insignificant and, like in the trade regressions (Panel D of Table 4) and analogously to Panel D of Table 5, sometimes even negative.

Overall, the results in Tables 4 to 6 suggest that neither StD nor DtS trust play a role for international migration flows. In fact, the different IV strategies yield remarkably similar results to the case where trade flows are the dependent variable. In both settings, the IV strategy proposed by GSZ is validated by the statistical tests but it yields coefficients that are not robust. Across all estimations, the IV strategy that used the original measure of somatic distance in GSZ systematically lead to the largest trust coefficients. As soon as alternative measures of somatic distance are considered, the coefficients on the trust variable decreases and become negative in some cases.

\section{Conclusion}

This paper first examined the causal impact of bilateral trust on international trade patterns. Under bilateral trust we understand the trust that citizens from a potential destination (importing) country have towards citizens from a potential source (exporting) country, which we referred to as "Destination-to-Source (DtS) trust". We analyzed this relationship in a gravity-type framework which allows us to control for a wide array of determinants for trade suggested by the literature. Moreover, employing panel data allowed us to include time varying national dummies that account for many unobserved factors. As we still suspect bilateral trust to be endogenous, we followed GSZ and used two measures of cultural proximity of country-pairs as instrumental variables: a measure of somatic distance and an indicator of religious similarity. Using exactly the same measure of somatic distance as GSZ, the estimation results are very similar to theirs. The OLS coefficients on bilateral trust are insignificant and small in magnitude but the significant IV coefficients suggest that an increase in DtS trust of one standard deviation increases aggregated export flows on average by 24 percent.

The picture changes dramatically when instrumenting bilateral trust with alterna- 
tive measures of somatic distance. Interestingly, the exact measure of somatic distance seems to matter a lot for second-stage results, although first-stage results on the impact of a change in somatic distance on bilateral trust are similar across the eight measures we use. In fact, our seven alternative estimates to GSZ typically contradict the results found in the first place. The trust coefficients not only lose their significance, but also the point-estimates decrease and even become negative. In contrast to GSZ, although using similar data and following their basic identification strategy, we find little evidence that average bilateral trust between country-pairs has a causal effect on international trade patterns. We conclude that by using just one specific indicator for somatic distance, GSZ mistakenly rejected the null hypothesis of no effect of higher bilateral trust on trade.

We next asked whether bilateral trust affects a migrant's decision to move abroad. Here, we distinguished two types of bilateral trust: the trust that people living in a potential source country grant citizens from a potential destination country (StD trust), and vice versa (DtS trust). To separately analyze the effects of StD trust and DtS trust we defined two gravity-type specifications and performed the same sensitivity analysis in the context of international migration as we applied in the context of the international trade. The patterns are very similar in these two settings. Applying the IV strategy with the same somatic distance measure as proposed by GSZ, we find second-stage estimates which suggest that an increase in StD trust or DtS trust of one standard deviation increases gross immigration flows on average by 66 percent and 56 percent, respectively. However, these economically and statistically significant effects disappear as soon as we use alternative measures of somatic distance as instrumental variables for bilateral trust. In other words, like for trade, we do not find any robust evidence which allows us to conclude that bilateral trust affects international migration flows.

Overall, this study highlights the fragility of IV estimations of the effect of bilateral trust on international trade and international migration. More importantly, we find that already small changes in the construction of the measures of somatic distance used 
for instrumentation of trust completely overturn the results. This holds true although all the somatic distance indicators are equally correlated with trust and valid.

More generally, our analysis suggests an important caveat on IV estimations in the case where there is a large degree of freedom in constructing an instrument. Neither statistical tests nor the theoretical plausibility of a potential instrument are sufficient to draw robust conclusions on causal effects. A thorough sensitivity analysis with alternative and equally valid instruments is indispensable.

\section{References}

Aghion, P., Algan, Y., Cahuc, P. and Shleifer, A. (2010). Regulation and distrust, Quarterly Journal of Economics 125 (3), 1015-1049.

Akerlof, G. A. (1970). The market for "lemons": Quality uncertainty and the market mechanism, Quarterly Journal of Economics 84 (3), 488-500.

Alesina, A. and La Ferrara, E. (2000). Participation in heterogeneous communities, Quarterly Journal of Economics 115 (3), 847-904.

Algan, Y. and Cahuc, P. (2010). Inherited trust and growth, American Economic Review 100 (5), 2060-2092.

Anderson, J. E. (1979). A theoretical foundation for the gravity equation, American Economic Review 69 (1), 106-116.

Anderson, J. E. (2011). The gravity model, Annual Review of Economics 3, 133160.

Anderson, J. E. and van Wincoop, E. (2003). Gravity with gravitas: A solution to the border puzzle, American Economic Review 93 (1), 170-192.

Anderson, J. E. and van Wincoop, E. (2004). Trade costs, Journal of Economic Literature 42 (3), 691-751.

Anderson, T. W. and Rubin, H. (1949). Estimation of the parameters of a single equation in a complete system of stochastic equations, Annals of Mathematical Statistics 20 (1), 46-63. 
Angrist, J. D. and Krueger, A. B. (1991). Does compulsory school attendance affect schooling and earnings? Quarterly Journal of Economics 106 (4), 979-1014.

Angrist, J. D. and Krueger, A. B. (2001). Instrumental variables and the search for identification: From supply and demand to natural experiments, Journal of Economic Perspectives 15 (4), 69-85.

Angrist, J. D. and Pischke, J.-S. (2009). Mostly Harmless Econometrics: An Empiricist's Companion, Princeton University Press, Princeton.

Arrow, K. J. (1972). Gifts and exchanges. Philosophy $\&$ Public Affairs 1 (4), 343-362.

Baldwin, R. and Taglioni, D. (2006). Gravity for dummies and dummies for gravity equations, CEPR Discussion Paper 5850.

Baum, C. F., Schaffer, M. E. and Stillman, S. (2007). Enhanced routines for instrumental variables / generalized method of moments estimation and testing, Stata Journal 7 (4), 465-506.

Beine, M., Docquier, F., and Ozden, C. (2011). Diasporas, Journal of Development Economics 95 (1), 30-41.

Beine, M. and Parsons, C. (2012). Climatic factors as determinants of international migration, Université catholique de Louvain, Institut de Recherches Economiques et Sociales (IRES), Discussion Paper No. 2012002.

Biasutti, R. (1959). Le Razze e i Popoli della Terra, Unione Tipogra co - Editrice Torinese, Turin, 3rd edition.

Bjornskov, C. (2006). The multiple facets of social capital, European Journal of Political Economy 22 (1), 22-40.

Bjornskov, C. and Meon, P.-G. (2010). The productivity of trust, Université Libre de Bruxelles, CEB Working Paper No. 10-042.

Bloom, N., Sadun, R., and Reenen, J. V. (2009). The organization of firms across countries, NBER Working Paper No. 15129.

Borjas, G. J. (1987). Self-selection and the earnings of immigrants, American Economic Review 77 (4), 531-553. 
Borjas, G. J. (1989). Economic theory and international migration, International Migration Review 23 (3), 457-485.

Chernozhukov, V. and Hansen, C. (2008). The reduced form: A simple approach to inference with weak instruments, Economics Letters 100 (1), 68-71.

Clark, X., Hatton, T. J., and Williamson, J. G. (2007). Explaining U.S. immigration, 1971-1998, Review of Economics and Statistics 89 (2), 359-373.

Coleman, J. S. (1994). Foundations of social theory, Harvard University Press, Harvard.

DeBruine, L. (2002). Facial resemblance enhances trust, Proceedings of the Royal Society of London 269 (1498), 1307-1312.

Dufour, J.-M. (2003). Identification, weak instruments, and statistical inference in econometrics, Canadian Journal of Economics 36, 767-808.

Dyer, J. H. and Chu, W. (2003). The role of trustworthiness in reducing transaction costs and improving performance: Empirical evidence from the United States, Japan, and Korea, Organization Science 14 (1), 57-68.

European Commission (1970). European Communities Study February-March 1970. GESIS Data Archive: ZA0626, dataset version 2010.

European Commission (1976). Eurobarometer 6 (November 1976). GESIS Data Archive: ZA0990, dataset version 2010.

European Commission (1980). Eurobarometer 14 (October-November 1980). GESIS Data Archive: ZA1039, dataset version 2010.

European Commission (1983). Eurobarometer 20 (October 1983). GESIS Data Archive: ZA1319, dataset version 2010.

European Commission (1986). Eurobarometer 25 (April 1986). GESIS Data Archive: ZA1543, dataset version 2010 .

European Commission (1990). Eurobarometer 33 (Spring 1990). GESIS Data Archive: ZA1753, dataset version 2010.

European Commission (1991). Eurobarometer 35.0 (March 1991). GESIS Data Archive: ZA2031, dataset version 2010. 
European Commission (1993). Eurobarometer 39.0 (March-April 1993). GESIS Data Archive: ZA2346, dataset version 2010.

European Commission (1994). Eurobarometer 41.1 (June-July 1994). GESIS Data Archive: ZA2491, dataset version 2010.

European Commission (1996). Eurobarometer 46.0 (October-November 1996). GESIS Data Archive: ZA2998, dataset version 2010.

Frankel, J., Stein, E., and Wei, S.-j. (1995). Trading blocs and the americas: The natural, the unnatural, and the super-natural, Journal of Development Economics 47 (1), 61-95.

Fukuyama, F. (1995). Trust: The social virtues and the creation of prosperity, The Free Press, New York.

Giuliano, P., Spilimbergo, A., and Tonon, G. (2006). Genetic, cultural and geographical distances, Institute for the Study of Labor, IZA Working Paper No. 2229.

Greif, A. (1993). Contract enforceability and economic institutions in early trade: The maghribi traders' coalition, American Economic Review 83 (3), 525-548.

Greif, A. (2000). The fundamental problem of exchange: A research agenda in historical institutional analysis, European Review of Economic History 4, 251-284.

Grogger, J. and Hanson, G. H. (2011). Income maximization and the selection and sorting of international migrants, Journal of Development Economics 95 (1), 42-54.

Grossmann, V. and Stadelmann, D. (2012). Wage effects of high-skilled migration: International evidence, World Bank Economic Review, forthcoming.

Guiso, L., Sapienza, P., and Zingales, L. (2003). People's opium? Religion and economic attitudes, Journal of Monetary Economics 50 (1), 225-282.

Guiso, L., Sapienza, P., and Zingales, L. (2004). The role of social capital in financial development, American Economic Review 94 (3), 526-556.

Guiso, L., Sapienza, P., and Zingales, L. (2008a). On-line appendix for cultural biases in economic exchange?

http://www.kellogg.northwestern.edu/faculty/sapienza/htm/onlineappendix.pdf.

Guiso, L., Sapienza, P., and Zingales, L. (2008b). Trusting the stock market, Jour- 
nal of Finance 63, 2557-2600.

Guiso, L., Sapienza, P., and Zingales, L. (2009). Cultural biases in economic exchange? Quarterly Journal of Economics 124 (3), 1095-1131.

Head, K. and Mayer, T. (2002). Illusory border effects: Distance mismeasurement inflates estimates of home bias in trade, CEPII Working Paper No. 2002-01.

Head, K. and Mayer, T. (2013). Gravity Equations: Toolkit, Cookbook, Workhorse, in: Gopinath, G., Helpman, E. and Rogoff, K. (eds.), Handbook of International Economics, Vol. 4, Elsevier.

Head, K., Mayer, T., and Ries, J. (2010). The erosion of colonial trade linkages after independence, Journal of International Economics 81, 1-14.

Kleibergen, F. and Paap, R. (2006). Generalized reduced rank tests using the singular value decomposition, Journal of Econometrics 133 (1), 97-126.

Kleibergen, F. and Schaffer, M. E. (2007), Ranktest: Stata module to test the rank of a matrix using the Kleibergen-Paap rk statistic, Statistical Software Components, Boston College Department of Economics.

Knack, S. and Keefer, P. (1997). Does social capital have an economic payoff? A cross-country investigation, Quarterly Journal of Economics 112 (4), 1251-1288.

Kollock, P. (1994). The emergence of exchange structures: An experimental study of uncertainty, commitment, and trust, American Journal of Sociology 100 (2), 313-345.

La Porta, R., de Silanes, F. L., and Shleifer, A. (1997). Trust in large organizations, American Economic Review 87 (2), 333-338.

Lewis, M., Simons, G., and Fennig, Ch. (2013). Ethnologue: Languages of the World, SIL International, Dallas, Texas, 16th edition. Online version: http://www.ethnologue.com.

Mayda, A. (2010). International migration: A panel data analysis of the determinants of bilateral flows, Journal of Population Economics 23, 1249-1274.

Mayer, T. and Zignago, S. (2011). Notes on CEPII's distances measures: The GeoDistdatabase, CEPII Working Paper No. 2011-25.

Murray, M. P. (2006). Avoiding invalid instruments and coping with weak instruments, Journal of Economic Perspectives 20 (4), 111-132. 
Ortega, F. and Peri, G. (2009). The causes and effects of international migrations: Evidence from OECD countries 1980-2005, NBER Working Paper No. 14833.

Ortega, F. and Peri, G. (2011). The aggregate effects of trade and migration: Evidence from OECD countries, IZA Discussion Paper No. 5604.

Paldam, M. (2000). Social capital: One or many? Definition and measurement, Journal of Economic Surveys 14 (5), 629-653.

Pedersen, P. J., Pytlikova, M., and Smith, N. (2008). Selection and network effects - migration flows into OECD countries 1990-2000, European Economic Review 52 (7), 1160-1186.

Putnam, R. D. (1993). Making Democracy Work: Civic Traditions in Modern Italy, Princeton University Press, Princeton.

Ravenstein, E. G. (1885). The laws of migration, Journal of the Statistical Society of London 48 (2), 167-235.

Rodrik, D. (2000). How far will international economic integration go? Journal of Economic Perspectives 14 (1), 177-186.

Roto, J. (2011). Population density in 2010. Nordregio, www.nordregio.se.

Roy, A. D. (1951). Some thoughts on the distribution of earnings, Oxford Economic Papers 3 (2), 135-146.

Sjaastad, L. A. (1962). The costs and returns of human migration, Journal of Political Economy 70 (5), 80-93.

Staiger, D. and Stock, J. H. (1997). Instrumental variables regression with weak instruments, Econometrica 65 (3), 557-586.

Stanners, D. and Bourdeau, Ph. (1994). Europe's Environment: The Dobris Assessment. European Environment Agency, Copenhagen.

Stock, J. H., Wright, J. H., and Yogo, M. (2002). A survey of weak instruments and weak identification in generalized method of moments. Journal of Business $E_{3}$ Economic Statistics 20, 518-529.

Stock, J. H. and Yogo, M. (2005). Testing for weak instruments in linear IV regression, in: Andrews, D. W. K. and Stock, J. H. (eds.), Identification and Inference for 
Econometric Models: Essays in Honor of Thomas Rothenberg, Cambridge University Press, Cambridge, 80-108.

Tabellini, G. (2008). The scope of cooperation: Values and incentives, Quarterly Journal of Economics 123 (3), 905-950.

Tabellini, G. (2010). Culture and institutions: Economic development in the regions of Europe, Journal of the European Economic Association 8 (4), 677-716.

Wooldridge, J. M. (2010). Econometric Analysis of Cross Section and Panel Data, MIT Press, Cambridge, 2nd edition.

World Value Survey (2009). 1981-2008 Official aggregate v.20090901. World Values Survey Association (www.worldvaluessurvey.org). Aggregate File Producer: ASEP/JDS, Madrid.

Zak, P. J. and Knack, S. (2001). Trust and growth, Economic Journal 111 (470), 295-321. 


\title{
Authors
}

Volker GROSSMANN

University of Fribourg; CESifo, Munich; Institute for the Study of Labor (IZA) Bonn. University of Fribourg, Bd. de Pérolles 90, CH-1700 Fribourg, +41 (0) 26 300-9383 volker.grossmann@unifr.ch

\section{Eva SPRING}

University of Fribourg. Address: University of Fribourg, Department of Economics, Bd. de Pérolles 90, F410, 1700 Fribourg, Switzerland. Phone: +41 (0) 2630093 82. Email: eva.spring@unifr.ch

\begin{abstract}
Trust in the citizens of a potential partner country may affect the decision to trade with or to migrate to a foreign country. This paper employs panel data to examine the causal impact of such bilateral trust on international trade and migration patterns. We apply instrumental variables (IV) approaches that capture the exogenous variance of bilateral trust separately with eight indicators of genetic ("somatic") distance between country-pairs. These indicators work equally well at the first stage. However, second-stage results very much depend on the exact measure employed as instrument. Overall, we find little evidence that bilateral trust affects international movements of goods and labor. More generally, we highlight the potential fragility of IV estimations even when the instruments seem plausible on theoretical grounds and when standard statistical tests confirm their validity.
\end{abstract}

\section{Keywords}

Bilateral trust; International migration; International trade; Instrumental variables; Somatic distance

\section{JEL Classification \\ F10, F22, Z10}

\section{Citation proposal}

Spring Eva, Grossmann Volker. 2013. «Does Bilateral Trust Affect International Movement of Goods and Labor?». Working Papers SES 442, Faculty of Economics and Social Sciences, University of Fribourg (Switzerland)

\section{Working Papers SES}

Last published:

434 Gmür M., Gmür M.: Bezahlte Freiwilligenarbeit - ein Widerspruch?; 2012

435 Gmür M., Wolf M., Schafer J.: Professionelles Management und Zielerreichung im Verein; 2012

436 Felbermayr G., Grossmann V., Kohler W.: Migration, International Trade and Capital Formation: Cause or Effect?; 2012

437 Schafer J.: Erfolgsfaktoren der Nachwuchsförderung in Sportverbänden; 2012

438 Zeides R., Gmür M.: Management Excellence in Pflegeeinrichtungen; 2012

439 Bosch P.: Value Relevance of the Fair Value Hierarchy of IFRS 7 in Europe. How reliable are mark-to-model Fair Values?; 2012

440 Gmür M.: Finanzierungsmix und Effizienz in spendensammelnden Organisationen; 2013

441 Grossmann V., Schäfer A., Steger T.: Migration, Capital Formation, and House Prices; 2013

\section{Catalogue and download links:}

http://www.unifr.ch/ses/wp

http://doc.rero.ch/collection/UNIFR WORKING PAPERS SES 